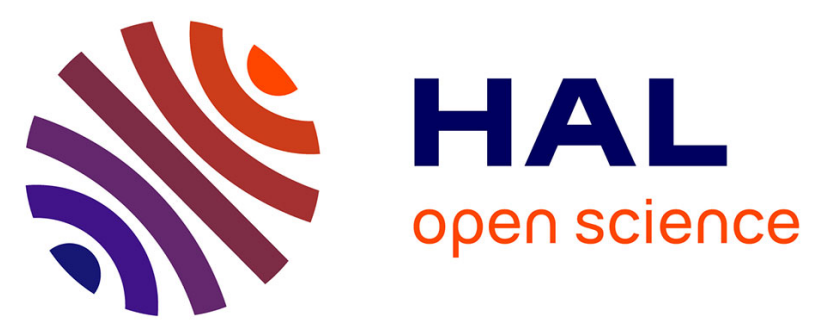

\title{
Between new and inherited technical behaviours: a case study from the Early Middle Palaeolithic of Southern France
}

Cyrielle Mathias, Laurence Bourguignon, Michel Brenet, Sophie Grégoire, Marie-Hélène Moncel

\section{To cite this version:}

Cyrielle Mathias, Laurence Bourguignon, Michel Brenet, Sophie Grégoire, Marie-Hélène Moncel. Between new and inherited technical behaviours: a case study from the Early Middle Palaeolithic of Southern France. Archaeological and Anthropological Sciences, 2020, 12 (7), pp.146. 10.1007/s12520020-01114-1 . hal-02908708

\section{HAL Id: hal-02908708 https://hal.science/hal-02908708}

Submitted on 12 Nov 2020

HAL is a multi-disciplinary open access archive for the deposit and dissemination of scientific research documents, whether they are published or not. The documents may come from teaching and research institutions in France or abroad, or from public or private research centers.
L'archive ouverte pluridisciplinaire HAL, est destinée au dépôt et à la diffusion de documents scientifiques de niveau recherche, publiés ou non, émanant des établissements d'enseignement et de recherche français ou étrangers, des laboratoires publics ou privés. 


\title{
Between new and inherited technical behaviours: a case study from the Early Middle Palaeolithic of Southern France
}

\author{
Cyrielle Mathias, Laurence Bourguignon, Michel Brenet, Sophie Grégoire, Marie-Hélène \\ Moncel
}

Title: Between new and inherited technical behaviours: A case study from the Early Middle Palaeolithic of Southern France.

\begin{abstract}
The beginning of the Middle Palaeolithic in Western Europe is traditionally associated with the emergence of new, more complex and standardised core technologies, such as Levallois technology. These changes occurred in the archaeological record between MIS 9 and MIS 6.

This paper aims to evaluate the processes of technical change at work in Southern France, tracking innovations and persistent behaviours, and potential shifts, to describe the process of transition and compare the Southeast and Southwest of France. We revised several major sites from Ardèche to Dordogne through the technological analysis of seven lithic assemblages in areas rich in good-quality raw materials, mostly flint. Technological analysis shows common features in lithic strategies and industries that can all be attributed to the Early Middle Palaeolithic. The features are a diversity of debitage methods and spatiotemporal management of the chaînes opératoires (ramification and artefact mobility). At the same time, algorithmic methods (Système par Surface de Débitage Alternées: SSDA) continue to be used, in the same way as Large Cutting Tools (LCTs), although they are rare (pebble tools, bifaces and "mixed matrices"). These LCTs are persistent technologies from the Acheulean technocomplex. Gradual mosaic-type changes in the lithic record are particularly well demonstrated through the sequence of Orgnac 3, where a local onset of Levallois core technologies appears to occur.

Both in the Southeast and Southwest of France, the Lower to Middle Palaeolithic transition records gradual and asynchronous behavioural changes as early as MIS 9 to MIS 6. These shifts are not only due to increased hominin cognition. Abilities of human groups to adapt to diversified environments and regional cultural processes may also have played a key role. Several lithic technocomplexes coexisted between MIS 9 and 6 in these two areas and although differences in local strategies are obvious, similar trajectories towards MP behaviour can be detected.
\end{abstract}

Key-words: Lithic Technology; Morphological analysis; Early Middle Palaeolithic; Southern France; Lower to Middle Palaeolithic Transition

\section{Introduction}

The emergence of Middle Palaeolithic (MP) technical behaviours in Western Europe was a long process, covering the period between MIS 9 and 6, during most of the second half of the Middle Pleistocene (Fig. 1). Standardised and productive debitages were initially used around 350-300 ky in several European areas (White et al. 2003, 2011; Moncel et al. 2005, 2011, 2012; Picin et al. 2013; Adler et al. 2014; Wiśniewski 2014; Malinsky-Buller 2016; Soriano and Villa 2017; Picin 2018). Studies show that these Middle Palaeolithic behaviours appeared in a mosaic-type way according to the region (Hérisson et al. 2016a, b; Picin 2018). For about 150 ky, we observe what seems to be a high diversity of lithic assemblages and technological behaviours (Brenet et al. 2008a; Colonge et al. 2010; Brenet et al. 2014; Carmignani et al. 2017).

In France, the first recognition of Middle Palaeolithic technology before the last interglacial dates back to the 1980s, with the discovery of sites such as Vaufrey Cave in Southwest France and Biache-Saint-Vaast in Northern France (Rigaud 1988; Tuffreau and Sommé, 1988). These sites have deeply renewed our knowledge of the onset of the Middle Palaeolithic. In the past 30 years, new excavations of multistratified sequences and the development of rescue archaeology in Europe and in France in particular have greatly enhanced our knowledge (Jarry et al. 2007; Raynal 2007; Bourguignon et al. 2008; Moncel 2008; Moncel et al. 2012; Hérisson 2012; Hérisson et al., 2016a; Van Baelen 2017, to cite a few). Moreover, data indicate that the South of Europe was permanently 
occupied, even during glacial periods, contrary to northern areas (Bennett and Provan 2008; Hublin and Roebroeks 2009; Dennell et al. 2011; Nieto Feliner 2011). This seemingly permanent human occupation in the south offers the opportunity to compare the lithic record at the same period and test gradual versus punctuated changes over time in hominin technical behaviours. In Southern France, as elsewhere in Europe, various types of industries coexisted from MIS 9-6 (Fig. 1). Some are characterized by Levallois technology, others by biface production and others again by both flaking and shaping.

In this study, we aim to compare, for the first time, technological behaviours from south-eastern and south-western France during the final Middle Pleistocene. Through the study of selected series, we aim to identify the technical systems involved and to compare them to other sites in the South of France. The objective is to try to establish whether early MP behaviours in two different geographical areas were similar, regardless of regional specificities, or whether they show regional and local features.

\section{EMP from Southern France and studied corpus \\ 2.1. Cultural areas from Southern France between MIS 9 and 6}

Three regional ensembles can currently be distinguished:

- South-eastern area (Rhône valley and surroundings). The few sites are mostly multistratified sequences in karstic contexts. The raw material environment is rich in varied flint outcrops, which are the most widely used raw materials at a majority of sites. Other diversified raw materials are available in alluvial deposits (basalt, quartz, quartzite, limestone, etc.). The oldest site is Orgnac 3, dated from MIS 9 and 8 (Moncel et al. 2011, 2012; Michel et al. 2013). Subsequent major Early Middle Palaeolithic (EMP) sites include Payre (MIS 8-6 - Moncel 2008), la Baume Bonne (MIS 8-6- Gagnepain and Gaillard 2003), Bau de l'Aubesier (MIS 7 - Carmignani et al. 2017) and Sainte Anne 1 (MIS 6 - Raynal 2007). Persistent bifacial technology can be found in the recent stratigraphic units of Lazaret Cave, dated to MIS 6, and described as Upper Acheulean (Lumley 2004);

- Pyrenees-Garonne area. The sites in this region are mainly open-air localities. The available raw materials are mostly quartz and quartzite, associated with other diversified raw materials (hornfels, sandstone, rare sources of flint in the Pre-Pyrenees, etc.). Over the past decade, several sites have been excavated in preventive archaeological contexts, enriching the corpus (Colonge et al. 2010; Jarry 2010). This area is known for its Acheulean typology, characterised by the presence of large cutting tool (LCT) production (bifaces, picks and cleavers sensu stricto), associated with discoid and bipolar-on-anvil productions (Acheuléen Pyrénéo-Garonnais: Mourre and Colonge 2007; Jarry 2010). One of the major EMP sites is Les Bosses (Jarry et al. 2007), at the transition between MIS 9 and 8, ca 300 ky. Only a few radiometric dates exist, however, for this region (Jarry et al. 2007; Hernandez et al. 2012). In addition, only a few karstic sites yielded lithic series associated with faunal remains: Montmaurin caves (Gaillard 1982; Thiam 2018) and Le Prône (Jaubert and Servelle 1996), and the chronological framework at these sites is not yet clear;

- South-western area (north of the Aquitaine Basin). This region comprises karstic and open-air occupations but multistratified sites are scarce. As in the south-eastern area, flint outcrops are numerous, and flint is the main raw material in a majority of sites. The oldest EMP site is La Micoque, level L2/3, occupied during MIS 10/9 (Delpech et al. 1995; Falguères et al. 1997). Open-air sites recently excavated in preventive archaeological contexts are numerous, particularly near the town of Bergerac, with occupations between MIS 9/8 and 6 (Bourguignon et al. 2008; Brenet et al. 2008a; Brenet 2013). In addition, a specific lithic technocomplex named 'Southern Acheulean' (Acheuléen meridional) had already been identified in the past (Bordes 1971; Turq et al. 2010). It was initially defined in the lower layers of Combe-Grenal and Pech-de-l'Azé II, on the basis of the presence of core-like bifaces and cleavers. The revision of old collections and new excavations changed this initial definition to the absence of flake cleavers, some bifaces, a trifacial concept of production and various debitage methods (Boëda 1989; Mourre 2003a; Colonge et al. 2010; Turq et al. 2010). Assemblages attributed to this lithic 
technocomplex are dated between MIS 8 and 6 (lower levels of Vaufrey Cave: Rigaud 1988; Les Pendus: Garreau 2000; Combe Brune 3: Folgado et al. 2005; Barbas C'4 lower: Chevrier 2006).

\subsection{Presentation of the studied corpus}

\subsubsection{Orgnac 3 (Orgnac-1'Aven, Ardèche), levels 7,6 and 2}

The Orgnac 3 site is located in the Rhône Valley, between the Ardèche and Cèze rivers. The site was excavated between 1959 and 1972 by Combier and his team.

The site evolved through karstic processes from an aven into a cave and then became a rock shelter before the final stage of site formation into an open-air site (Joly 1947; Combier 1967; Debard 1987). Ten archaeological layers were recognised, containing abundant lithic pieces and faunal remains (Combier 1967; Moncel 1999). Fauna is dominated by equids or cervids, depending on the level, represented by various species (Moncel et al. 2005). The faunal association (including micromammals) and pollen spectrum are typical of a Mediterranean forest environment in the lower levels, whereas a more open, cold and dry environment is suggested from level 2 upwards, with the replacement of Equus mosbachensis by Equus steinheimensis (Jeannet 1981; Gauthier 1992; Forsten and Moigne 1998; Sam and Moigne 2011).

The site is dated to MIS 9 for the lower layers and to the beginning of MIS 8 for levels 1 and 2, according to radiometric dates and biochronology (Moigne and Moncel 2005; Michel et al. 2011, 2013). Volcanic ashes lying above level 2 are dated to around $300 \mathrm{ky}\left(302 \pm 2.9 \mathrm{ky}\right.$ : Michel et al. $2011 ; 308 \pm 6 \mathrm{ky}$ by ${ }^{40} \mathrm{Ar} /{ }^{39} \mathrm{Ar}$ : Michel et al. 2013).

Lithic components show a change in the sequence with the appearance of the Levallois concept in the middle part of the stratigraphy and the progressive disappearance of bifaces (Moncel, 1999; Moncel et al., 2011, 2012). Carcass processing also seems to become more standardised, as shown by the location, type and intensity of cut marks (Moigne and Moncel 2005).

Three levels were selected for this study: 7, 6 and 2. Levels 7 and 6 were formed when the site was a cave, whereas level 2 corresponds to a rock shelter occupation. They may correspond to one large occupation or several repeated ones.

\subsection{2. $\quad$ La Micoque (Les Eyzies-de-Tayac, Dordogne), level L2/3}

La Micoque site has been known for a long time, following excavations since the end of the nineteenth century by multiple researchers (G. Chauvet, E. Rivière, L. Capitan, E. Harlé, D. Peyrony, O. Hauser and F. Bordes). The latest excavations were carried out by J.-Ph. Rigaud and A. Debénath between 1983 and 1996 using modern methods. This work focuses on the lithic collections from the latter excavations: due to the considerable number of excavators, stratigraphic correlations between ancient and new excavations are often difficult, although some correlations have been attempted (Rosendahl 2006).

The site consists of an occupation at the bottom of a cliff, and not a rock shelter as previously thought. Geoarchaeological studies show that two main processes were responsible for site formation: slope wash and alluvium deposits. Three stratigraphic ensembles were defined (Texier 2006a, b). Fauna is preserved and composed essentially of herbivores (mainly horses, cervids and bovids). Proportions differ according to the layer, but Equus mosbachensis micoquii is always dominant (Delpech et al. 1995; Langlois 2004, 2005).

Correlations with the Vézère alluvium deposits (Fw1 and Fw2; Texier and Bertran 1993; Texier 2006a) were combined with radiometric ages obtained by Electron Spin Resonance coupled with Uranium-Thorium (313 $\pm 47,293 \pm 44$ and $291 \pm 44$ ky by ESR/U-th: Falguères et al. 1997) and place level L2/3 at the end of MIS 10. Contrary to the overlying and underlying levels, level L2/3 is clearly less altered (little desilicification and absence of taphonomic fractures and notches). This allows a precise technological analysis of lithic artefacts.

\subsubsection{Petit-Bost (Neuvic-sur-l'Isle, Dordogne), level 2}

Petit-Bost is an open-air site, excavated in the context of preventive archaeological operations in 2001 by L. Bourguignon. The site is located in the Isle Valley (between Mussidan and Périgueux), near other Palaeolithic 
sites such as Croix de Canard (Detrain et al. 2005). The excavated surface covers 3,348 $\mathrm{m}^{2}$, with a concentration of artefacts in an area of $635 \mathrm{~m}^{2}$. As in many open-air sites in this area, fauna is not preserved.

Three layers were revealed (Bourguignon et al. 2008; Djema 2008). Level 0 corresponds to artefacts overlying the palaeosol, which may be earlier than the Eemian. Level 1 is the best-preserved level, situated in the upper part of the palaeosol (B'tg). Solifluction processes have affected the lithic assemblage of this level without affecting its overall integrity (it contains a high percentage of refits). Finally, artefacts from level 2 are situated in a gravel layer at the bottom of the palaeosol. Contrary to the precedent assemblage in level 1, this lithic assemblage was disturbed and is not homogeneous (it only contains a few refits). However, this layer is the only well-dated layer by Thermo Luminescence (TL), between 270 and $340 \mathrm{ky}$ (Lahaye 2005; Bourguignon et al. 2008). Thus, the fact that the level may be a sort of palimpsest has to be taken into consideration when interpreting the results.

\subsubsection{Pech-de-l’Azé II (Carsac-Aillac, Dordogne), level 7}

Pech-de-l'Azé II Cave forms part of a complex of five sites, covering a period from the Acheulean to the Mesolithic. Pech-de-l'Azé II is an occupation in the entrance of a long tubular cave. At the other extremity of the cave lies the Pech-de-l'Azé I site, with a rich Mousterian sequence (Bordes 1954; Soressi et al. 2008). Contrary to the first interpretations of F. Bordes, there is no correspondence between these two sites.

Pech-de-l'Azé II was one of the first of these sites to be excavated. It was first discovered in 1948 by M. Bourgon and F. Bordes and then excavated by the latter between 1949 and 1951 and 1967 and 1969. The upper layers correspond to the Mousterian, while layers 6 to 9 were attributed to the Southern Acheulean, contributing to its definition (Bordes 1971).

Four lithostratigraphic units were distinguished (Texier 2006b). Level 7 is part of Unit 2, which corresponds to a mass flow, or a flow associated with a moderate scree formation.

Levels 7 to 9 were dated to between 140 and 180 ky by Optically Stimulated Luminescence (OSL), with two dates for level 7 (170 $\pm 8 \mathrm{ky}$ and $143 \pm 9 \mathrm{ky}$ : Jacobs et al. 2016). Previous ESR ages placed levels 6-9 between $117 \pm 13 \mathrm{ky}$ and $175 \pm 27 \mathrm{ky}$ (Grün and Stringer 1991; Grün et al. 1991). Fauna is dominated by equids and bovids, associated with Cervus elaphus, Ursus sp. and Rhinoceros mercki (Prat 1968). Fireplaces were also noted by F. Bordes in layer 7 during excavations (Bordes 1971). A bias exists due to the collection of only tools and large lithic pieces during those excavations (presence of numerous by products in the slope in front of the site, corresponding to spoil from old excavations), which must be taken into consideration in techno-economic interpretations.

\subsubsection{Combe Brune 2 (Creysse, Dordogne), level VIIa}

The open-air site of Combe Brune 2 was excavated during preventive archaeological operations in 20062007 by M. Brenet and M. Folgado (Brenet et al. 2008b; Brenet 2013). It is located on the ridge of the Pécharmant limestone plateau (near Bergerac), in a rich archaeological context. Several Lower and Middle Palaeolithic sites are located nearby: Combe Brune 3, Les Pendus, Barbas 1 and Cantalouette 1 (Boëda et al. 1996; Garreau 2000; Folgado et al. 2005; Brenet et al. 2006; Brenet et al. 2008a; Brenet and Folgado 2009).

In Combe Brune 2, two areas (east and west) were excavated, yielding several levels of occupation preserved in sinkholes. Most of these correspond to the Early and Late Middle Palaeolithic, but one Upper Palaeolithic layer was also uncovered at the bottom of a sinkhole. Mechanical processes (e.g., mechanical shovels) used during the excavations may partly explain the lack of flakes smaller than $2 \mathrm{~cm}$.

Level VIIa is considered in this study. It corresponds to a large karstic depression (sinkhole) in the western area with a four-metre-thick stratigraphy. Deposits derive from colluviums, linked to the reworking of Tertiary alluviums and alterites near the site (Brenet et al. 2008b). Six archaeological layers were uncovered in this part of the site, all attributed to the Early Middle Palaeolithic.

A combination of geological and geomorphological approaches and luminescence dating places these Early Middle Palaeolithic levels between the end of MIS 7 and the beginning of MIS 6 (Frouin et al. 2014). The base of the sinkhole is dated to $234 \pm 25 \mathrm{ky}$. 


\section{Method}

3.1. Raw material module characterisation

Raw materials were determined on the basis of published works, regional raw material comparative collections and some specific sampling (Séronie-Vivien and Séronie-Vivien 1987; Moncel and Combier 1992; Turq 2000; Fernandes et al. 2008, 2012; Fernandes 2012; Grégoire 2012; Turq et al. 1999, 2011, 2017; Morala 2017; Moncel et al. 2019). They were distinguished by microscopic analysis with a stereomicroscope. Considering the lithological context of the studied sites, flint facies were grouped together and characterised in order to correlate them with available regional resources (when possible) and to identify techno-economic practices. Macroscopic determination does not allow for the precise association of a sample with an outcrop. In relation to the main objectives, sorting focused mainly on the type of blank, raw material type and flint facies group.

Both the Ardèche and Dordogne areas are rich in flint outcrops. In Ardèche/Gard, flint slabs can be collected in the riparian basin of Barjac-Issirac and nodules near Laval-Saint-Roman in the Rhône alluviums of Alpine origin (Grégoire 2012; Fernandes 2012). Further north of Orgnac 3, flint outcrops are diversified with Barremian and Barremo-Bedoulian flints, for example (Fernandes 2012; Moncel et al. 2019). Other raw materials, such as limestone pebbles, basalt, quartz and quartzite can be collected in the Cèze, Ardèche and Rhône alluvial deposits. In Dordogne, flint outcrops are almost all from the Senonian. Detailed data can be consulted in Turq et al. (2017). Senonian flints can be collected in all the valleys of the Dordogne, Vézère and Isle rivers in the form of nodules, blocks and pebbles (Turq et al. 1999; Turq 2000; Morala 2017). Some types are of particular interest here, such as the Senonian with pyrite inclusions of the Belvès type in the Enea valley near Pech-de-l'Azé II (Turq 2005). The Bergeracois flints from the Upper Campanian are also preferential outcrops. In the south of the area, Tertiary chalcedony is available and, in the east, Jurassic flints (Turq et al. 2017). Pebbles of other diversified raw materials can also be collected in the alluviums (quartz, limestone, basalt, etc.).

\subsection{Technological analysis}

A technological analysis was conducted on the lithic material in order to identify and describe the reduction processes by applying the concept of the chaîne opératoire (systemic approach - Leroi-Gourhan 1964; Creswell 1996; Inizan et al. 1995; Pelegrin 1995), including both qualitative and quantitative attributes. This concept was chosen as a tool to place each artefact in its technical sequence.

The aim of this study is to investigate the main processes performed in each occupation from raw material selection to the production of end products. In order to fulfil these purposes, all the lithic components (e.g., debris, flakes, cores and tools) from each site were analysed. While techno-economic studies have been conducted recently, this study focused in particular on cores and tools (including flake tools and LCTs). The whole lithic assemblage, however, has also been revised in for the lithic series of Petit-Bost (Bourguignon et al. 2008; Djema 2008) and Combe Brune 2 (Brenet et al. 2008b; Brenet 2013). The analysis of the whole assemblage is essential in order to investigate and describe changes in technical behaviours over time and between sites. Sampling a lithic series is not propitious to an understanding of all the technical processes used, nor is it conducive to discussions of the question of variability and adaptation to raw materials.

Classical lithic technology attributes were used to study each artefact: raw material, technological category, shape, fragmentation, organisation, number and organisation of scars, striking platform (on cores and flake butts) and percentage of remaining cortex (Boëda et al. 1990; Inizan et al. 1995; Geneste 1985; Baena et al. 2017). Morphometric data were taken from the technical axis of the flake (length, width and thickness; Debénath and Dibble 1994). A technomorphological study was applied to cores: number of striking and flaking platforms, organisation and chronology of scar removals, convexities, end products and diacritic schemes (Dauvois 1976).

\subsection{Reduction processes and terminology used}

The 'diachronic' (through time) or 'synchronous' (at the same time) technical sequences at the scale of the chaine opératoire were considered. At the scale of the artefact, the concept of the 'matrix management system', which includes recycling processes, was employed (Faivre 2011; Amick 2014).

Three types of processes were described: 
- "Simple": the object is manufactured as a whole (core, biface, etc.);

- "With successive distinct phases of manufacture": the status of the object can change during manufacture (from a core to a tool, a flake to a core, a core to a hammer, etc.), so recycling can be included in the different phases (Amick 2014);

- "Mixed or undifferentiated": The status of the object is ambivalent, between flaking and shaping, for example. It may be considered as a tool or a core and can be both (see McPherron 2007, and papers therein). This is the case for some bifacial or trifacial pieces (Boëda 1989; Brenet and Folgado 2009; Brenet et al. 2014) or the carinated pieces produced during the Upper Palaeolithic (Almeida 2001).

Particular types of organisation of reduction processes are investigated, such as ramification (branching strategies - Bourguignon et al. 2004; Brenet et al. 2014). The following categories of reduction processes were used for this analysis:

- Shaped productions: comprising unifaces, bifaces and pebble tools (or, more commonly, large cutting tools).

- Algorithmic debitages: corresponding to systems where a simple knapping algorithm is applied to the core. It includes the SSDA or High Lodge-type core technology (Ashton 1992; Forestier 1993) and Quina debitages (Bourguignon 1997). Methods are diversified, depending on the purposes of their end products. Flakes often have a large and open striking platform and a back (cortical or not). In the case of Quina debitage, dihedral and "à pans" platforms are typical, formed by the lateralisation of the debitage (Bourguignon 1997).

- Levallois technology: determined based on the six criteria defined by Boëda (1993 and 1994). Cores present two surfaces (one striking platform and one flaking platform). Convexities are managed and flakes are produced following a parallel or subparallel axis. Production can be lineal (one main and invasive flake or point) or recurrent with distinct orientations of the multiple removals (unipolar, bipolar and centripetal).

- Typo-Levallois technology: In some cases, cores present most but not all of the criteria defined by E. Boëda for the Levallois definition, even if similar end products were obtained. The process is similar, but the volume of the core is not totally managed. It corresponds to some simple prepared core technologies (SPCTs) described in British series (Bolton 2015).

- Discoid technologies: The parameters of Boëda (1993), Peresani (1998) and Mourre (2003b) were used. Cores are managed with two secant surfaces and the typical products are flakes with peripheral cutting edges and pseudo-Levallois points.

- Cores-on-flakes: a wide category. Specific productions exist, such as Kombewa (recurrent and lineal Owen 1938; Tixier and Turq 1999; see also Mathias 2016, for terminology), Kostienki (Turq and Marcillaud 1976); Nahr-Ibrahim (Solecki and Solecki 1970) and Le Pucheuil (Delagnes 1993). Some classical debitage concepts can also be performed on flakes (Levallois, discoid and Quina). All these productions may be considered as ramification (Bourguignon et al., 2004) or recycling (Amick 2014).

\subsection{Morphological analysis of retouched tools}

Retouched and shaped blanks were studied using a techno-morphological analysis (Lepot 1993; Bourguignon 1997; Soriano 2000; Boëda 2013; Frick and Herkert 2014), based on recent approaches to flake tools (Aureli et al. 2016; Rocca 2016; Rocca et al. 2016) and LCTs (Boëda et al. 2004; Donnart 2010; Chevrier 2012; Viallet 2016a).

The tool can be composed of distinct parts organised in a "structure". The aim is to study tool structures by means of the analysis of the volume and the edges: edge morphologies (in front, sagittal and section view), impact of retouch on the global shape, and edge angles. Callipers were used to measure angles at a depth of $4 \mathrm{~mm}$ from the edge with a conversion table (Dibble and Bernard, 1980; Claud, 2008). For angles higher than $70^{\circ}$, a diameter tape was used. Techno-Functional Units (TFUs) are deduced for each tool. Three elements make up the TFU (Lepot 1993; Boëda 2013):

- The working cutting edge, referred to as the transformative or active part (TFU T);

- The handled/hafted area, referred to as the prehensile part (TFU P); 
- A part that is receptive to/transmits the motion energy (TFU R). During the Lower and Middle Palaeolithic, TFU P and R made up a single component (TFU P/R; Lepot 1993).

There are several categories of TFU T: linear cutting edges, point-like, and point-like in association with a cutting edge. They can be rectilinear, convex, concave, etc. as determined by the front, sagittal and section views (Rocca 2016). These main categories were then used to compare retouched and unretouched productions. Retouched products are then considered in accordance with two hypotheses:

- Additional: Retouched products are found in addition to unretouched products with similar cutting edges and shapes. The purposes of the productions are identical.

- Complementary: Retouched products may be considered as complementary to unretouched products because of differences (cutting edges, configuration, and mass).

In this study, only technological and morphological features were considered, without microwear data. This constitutes a basis which enables us to advance further than typological studies.

\section{4. $\quad$ Results}

\subsection{Raw materials}

Debitage productions are preponderant for the whole corpus of sites (Table 2). LCTs are nevertheless always present, but in low quantities and are diversified: pebble tools, bifaces, unifaces or bifacial/trifacial undifferentiated/mixed "matrices". Flake tools are mainly side scrapers, followed by notches and denticulates.

\subsection{1. $\quad$ Orgnac 3}

Flint is the dominant raw material in all levels (level $7=94.2 \%$; level $6=99.57 \%$; level $2=97 \%$ ). Local flints from the Barjac-Issirac basin were preferentially used, collected as slabs between 3 and $5 \mathrm{~km}$ from the site. Sometimes, nodules and rounded slabs from the same formations were also collected on slopes and alluviums near the site. These flints formed in Tertiary lacustrine formations and are rich in charophyte and gastropod fossils, such as Striatella or Planorbis. However, better-quality modules for flaking were selected in level 2 than in levels 7 and 6 , from the same outcrops. In the lowest levels $(6,7)$, good-quality slabs were used for shaping bifaces.

The least used flints were blue/grey nodules from Laval-Saint-Roman and pebbles from the Rhône alluviums of Alpine origin $( \pm 15 \mathrm{~km})$. Oolithic flints from the Jurassic are more frequent in level 6 than in other layers. The provenance of these flints is still unknown, but they may come from an area farther north. Non-flint raw materials are diversified and only represented by a few pieces: quartz, limestone, sandstone or basalt. They can all be collected in alluviums (from the Ardèche, Cèze and perhaps from the Rhône rivers; i.e., 5 to $15 \mathrm{~km}$ away).

Products from all the steps of the chaines opératoires using local flint are present (flakes with different cortex ratios on the dorsal face, sharpening flakes, etc.). The situation is different for all the other materials, where reduction processes are partial, suggesting the introduction and mobility of artefacts.

\subsubsection{La Micoque, $\mathrm{L} 2 / 3$}

Raw materials are mainly composed of Senonian flints from local outcrops (98.8\%). They were collected as blocks, nodules or pebbles. In spite of desilicification, numerous bryozoan fossils can be observed, characteristic of Upper Cretaceous flints (Seronie-Vivien and Seronie-Vivien 1987; Morala 2017). Other raw materials are rarely used and correspond to two types of quartz (1.1\%) and a single piece of sandstone. No flint from the Bergerac area was identified, despite their characteristic fossils (particularly Orbitoides media).

Complete flint reduction processes are present. The smallest debris and sharpening/re-sharpening flakes suggest in situ knapping activities, including tool production and transformation.

\subsubsection{Petit-Bost, level 2}

The use of flint is predominant (95.5\%), and Tertiary chalcedony (0.7\%) and quartz pebbles (4\%) were collected occasionally. Grey/black or blond Senonian flints were mainly selected from the local environment (alluviums and alterites of the Isle valley and adjacent watercourses), in the form of nodules and pebbles. In addition, some Upper 
Campanian flints from the Bergerac area were used, transported from outcrops situated at $30 \mathrm{~km}$ from the site, as the crow flies (with characteristic Orbitoides media fossils and colour zoning; 0.7\%).

Local Senonian flints were employed for all the reduction processes in this level. Pieces in chalcedony and Bergeracois flint were introduced from outside. Some flakes and tools are in chalcedony, whereas only tools and tool-cores are in Bergeracois flint.

\subsubsection{Pech-de-1'Azé II, level 7}

Raw materials are mostly grey/black flints (sometimes blond) from the Senonian (77.8\%). Bryozoans and fragments of sponges are frequent inclusions. These flints can be found in the local environment $(3-11 \mathrm{~km})$ and are sometimes of poor quality. Senonian flints can also be collected as pebbles in the Enéa or Dordogne alluviums. A particular type was favoured, with significant inclusions of pyrite visible as small tubular nodules (Turq et al., 1999). Large Levallois flakes from good-quality Senonian flints indicate procurement from a distance far beyond the valley, given the relatively poor quality of local flints.

The use of other raw materials indicates diversified collecting. Chalcedony from the Bord plateau was also used and at least two types were identified (8.7\%). They may be collected on the plateau as slabs and cupules $(6 \mathrm{~km})$ or closer to the site in the Enéa or Dordogne alluviums. Quartz was also utilised, for debitage and pebble tools $(10.7 \%)$. A few pieces of basalt, limestone and fine-grained sandstone are also represented. All these raw materials can be collected in the local alluviums.

Little can be said about techno-economic behaviour, as only diagnostic pieces were gathered during the excavation. Despite this, some refits were made and sharpening flakes are present, although sparse.

\subsubsection{Combe Brune 2, level VIIa}

Flint is the dominant raw material (97.3\%). Quartzite (2.2\%) and chalcedony $(0.4 \%)$ were used sporadically. Highquality Bergeracois flint is the most widely employed: the site is established directly on the outcrops. This flint is from the Upper Campanian and quite characteristic with its colour zoning and Orbitoides media, Fallotia and Faujasia faujasii fossils (Fernandes et al. 2012; Morala 2017). These flints were mainly collected in local alterites (nodules, blocks, slabs, cupula), more rarely in alluviums (pebbles; $0.3 \%$ of the whole assemblage).

Local black Senonian flints (1\%), Tertiary chalcedony and quartz were also sometimes used, collected in the alluviums.

Knapping activities seem to have taken place on-site (producing flakes from the Bergeracois with different ratios of cortex), but due to the lack of products under $20 \mathrm{~mm}$, no particular conclusions can be reached regarding tool production and transformation.

\subsection{Lithic technology}

\subsubsection{Orgnac 3, level 7}

There is no clearly dominant flaking method. The cores show the use of alternant discoid-like methods. Half of the cores are flakes but due to the low number of cores, no statistical interpretations can be attempted. Flakes are produced by unipolar and bipolar SSDA methods (these types of cores are not present in the series). One mixed piece, combining a shaping and a flaking process, is also present.

\subsubsection{Orgnac 3 , level 6}

Algorithmic methods are mainly employed in this layer (SSDA; 40\% of the cores) (Fig. 6, F), followed by the typo-Levallois $(23.3 \%)$ and core-on-flake methods (14\% - Fig. 5, F). Other diverse methods are also represented: discoid-like and trifacial (one mixed matrix and one single matrix) (Fig. 9, C). One bifacial mixed matrix was also identified (Fig. 10, B).

Algorithmic methods mainly exploited two flaking surfaces. Some cores and flakes share features with the Quina flaking method, but also with some SSDA methods (Bourguignon, 1997). Typo-Levallois methods correspond to 
cores with two hierarchised surfaces, with management of the striking platform and convexities. Unipolar and bipolar methods are predominant, sometimes with invasive removals (Fig.2, F; Fig. 4, B).

\subsubsection{Orgnac 3, level 2}

The Levallois concept is dominant in this layer (Fig.2, all except F; Fig. 4, A, C). There is substantial debitage on flakes, associated with only a few other rare flaking methods, such as alternant (discoid-like) and SSDA methods.

Thus, $23.4 \%$ of the flakes greater than $1 \mathrm{~cm}$ and $59.6 \%$ of the cores are Levallois. The main method is the recurrent centripetal method, oriented toward the production of flakes with peripheral cutting edges and large butts. Some large lineal flakes are present; however, cores of this type are very rare (suggesting a repurposing of core exploitation? Or the introduction of the flakes?). Two types of blanks were selected: slabs and flakes (more than half of the cores are on flakes), showing extensive ramification and a microlithisation of part of the Levallois production. Some cores are exploited until the exhaustion of the slab, leading to accidents such as breakages at the end of reduction.

Cores-on-flakes or flaked-flakes ( $\mathrm{n}=64 ; 24.6 \%)$ are mainly composed of recurrent Kombewa cores (n=50; Fig. 4 $\mathrm{C}, \mathrm{E}$ and G). Some cores indicate the exploitation of both the dorsal and ventral surfaces, similar to the NahrIbrahim methods. In relation to the number of cores, there is a lack of products resulting from these productions $(\mathrm{n}=61)$, suggesting that these flakes may have been exported.

\subsubsection{La Micoque, L2/3}

Algorithmic methods are dominant, but the end products are nonetheless normalised (Fig. 6, A-B). The main objectives of production are backed and elongated flakes (with cortical or non-cortical backs). The elongation index is up to 1 in $70.6 \%$ and up to 1.5 in $33.6 \%$ of the entire flake sample. These flakes are produced with unipolar (more rarely bipolar) algorithmic flaking. Sequences are short: $71 \%$ of the flakes show between one and three removals on their dorsal face. Nonetheless, cores of this type are poorly represented. Cores are mainly manufactured by other algorithmic methods (SSDA, $n=18 ; 42.8 \%)$, but also cores-on-flakes $(n=10 ; 23.8 \%)$ and Levallois and typo-Levallois production ( $\mathrm{n}=7 ; 16.7 \%$ ) (Fig. 3, B; Fig. 4, E).

Algorithmic methods make use of unipolar and bipolar exploitation, mainly with two debitage surfaces. Few cores show four/five flaking surfaces.

Flakes used for debitage total 23.8\% (Fig. 4, E; Fig. 5, B). Kombewa methods are predominant (recurrent and lineal method are equally represented). Few flakes are exploited on the dorsal face or on both the dorsal and ventral faces. End products are morphologically different (with peripheral edges and biconvex cutting edges) from those derived from the main production methods, but no drastic decrease in size is apparent.

Levallois and typo-Levallois productions occur in low proportions $(16.7 \%)$. Their use is quite marginal in this level. Levallois products were already mentioned by J.-M. Geneste. Here, the matrix was not entirely manufactured (not the whole volume). Recurrent (unipolar, bipolar) and lineal methods were also used.

Some other flaking methods are represented by a few cores: alternant non-discoid cores or tested blocks. One mixed bifacial matrix is also present.

\subsubsection{Petit-Bost, level 2}

The study of the cores shows a preponderance of algorithmic and core-on-flake methods (respectively, $\mathrm{n}=26$, $27.1 \%$ and $\mathrm{n}=21,21.9 \%$ ). Algorithmic methods use only part of the core volume (Fig. 6, E). In most cases, two adjacent surfaces are exploited, but there are also cores with three and four exploited surfaces. End products are quadrangular flakes, with a large butt or a lateral back.

The proportion of cores-on-flakes is significant (21.8\%), and several reduction methods were applied (Fig. 4, D; Fig. 5, A, D). Mixed matrices are the most common with flakes with large notches (one or two notches or denticulates; 13.5\%). They can be considered as cores and tools as well (Fig. 5, D). Other methods used are Kombewa (lineal or recurrent) and the exploitation of ventral and dorsal surfaces (8.3\%). A reduction in the size of end products is observed for productions using flake matrices. 
Levallois flakes and cores are present in the lithic assemblage in low proportions (11.5\% of the cores). Recurrent unipolar and bipolar methods dominate, though some cores show recurrent centripetal exploitation (Fig. 3, E-F; Fig.4, D).

Level 2 of Petit-Bost shows some specific traits. This is the only assemblage where Quina reduction sequences (Bourguignon, 1997) are clearly established (9.4\% of the cores, with refits) (Fig. 6, C-D).

Ten pieces show the use of the trifacial concept (Boëda 1989; Chevrier 2006) (Fig. 9, B; Fig. 10, F). Three different methods were identified (Mathias and Bourguignon, 2019):

- a flake production matrix;

- a flake production matrix, subsequently retouched, or;

- a mixed matrix, mixing both flake production and the shaping of a tool.

This last method is the most widely employed, aiming for point-like active parts (TFU T).

\subsubsection{Pech-de-l’Azé II, level 7}

Several flaking systems have been identified: cores-on-flakes, Levallois, discoid or algorithmic (SSDA).

Cores-on-flakes are dominant (Fig. 5, I, K). Considering the biased collection of pieces, these productions may seem to be much more important than they really were. Flake thickness is taken advantage of, for a Pucheuil-like exploitation (Delagnes 1992, 1993; Lazuen and Delagnes 2014). Kombewa methods (lineal and recurrent) are also used. A refit was made on a chalcedony flake, split into two parts which were both then retouched.

The Levallois concept is not preponderant in this level. Differences exist between methods. Recurrent unipolar and bipolar Levallois methods are used, with convexity maintenance carried out by débordant (core-edge) flakes (Figure 3, D). Cores are quite small with manifest accidents; although large Levallois flakes from good-quality flints are also present (indicating a long reduction process? There are no intermediary Levallois flakes - suggesting that the large flakes are imports?).

A dichotomy exists in the systems used depending on raw materials. Cores-on-flakes and Levallois methods are commonly applied to flint or chalcedony materials, whereas discoid-like methods were employed on quartz. Discoid unifacial methods on quartz are prevalent, even if one core shows a bifacial modality. The objectives of production are flakes with peripheral cutting edges as opposed to a back (or butt).

\subsubsection{Combe Brune 2, level VIIa}

Several concepts of flake production were identified: mainly Levallois, cores-on-flakes, and discoid.

The use of the Levallois concept is preponderant in this level, accounting for $46.9 \%$ of the cores (Fig. 3, A, C; Fig. 4 , F). Recurrent unipolar and bipolar methods are used, with some cores showing recurrent centripetal and lineal exploitations. There are cores with some preparation corresponding to typo-Levallois production. These may be linked to the predominance of unipolar and bipolar Levallois exploitations in an expedient raw material context. Some pieces present a final sequence of exploitation which is no longer parallel but secant (form of recycling of the core driven by a change in production aims - cf. successive matrix management).

Cores-on-flakes (18.8\% of the cores) are exploited by recurrent Kombewa methods, often from the proximal edge (Fig. 5, H, and J). The dorsal face (Nahr-Ibrahim method), and both the dorsal and ventral faces are sometimes also exploited. Discoid cores (11.5\%) correspond to bifacial methods on flakes, in pursuit of pseudo-Levallois points or peripheral cutting edges. Other methods are atypical, but they are essentially morphologically discoid.

Some other methods are present but in low proportions: laminar unipolar/bipolar exploitations, SSDA (with one, two or three surfaces of exploitation) or tested blocks.

Three pieces display the trifacial concept; one is strictly oriented toward production whereas two are mixed matrices (Fig. 9, A). Point-like active parts appear to be the final aim. A bifacial mixed matrix was also identified. 


\subsection{Techno-morphological analysis of flake tools}

\subsubsection{Orgnac 3, level 7}

The collection yielded 36 retouched flakes, essentially made up of side scrapers $(55.6 \%)$ and notches and denticulates (27.8\%). Some other diversified tools are also present. Contrary to expectations, point-like TechnoFunctional Units with Transformative aims (TFU T, i.e., the supposed active part) were identified (point-like and point-like active parts associated with a linear cutting edge) (Fig. 7, A). Linear active parts correspond to the second-most-represented group and denticulates to the third. This is quite an unusual association. The category of retouched products complements the unretouched production of flakes, generating pieces with similar linear cutting edges.

\subsubsection{Orgnac 3, level 6}

Two hundred and fifty flake tools are essentially side scrapers (54.8\%), and notches and denticulates (28\%) associated with some points, becs and end scrapers. The often-invasive retouch intensively modifies initial blank morphology, sometimes in a Quina-like fashion. Contrary to level 7, the TFU Ts are linear (rectilinear) cutting edges, opposed to a lateral back or a large butt (TFU R/P) (Fig. 7, B). Secondarily, active punctiform areas (pointlike, which may or may not be associated with a cutting edge) and denticulates (Fig. 7, B) were clearly a final production aim. Thus, the retouched production is considered as principally additional to the unretouched production, where the purpose of both was linear cutting edges.

\subsubsection{Orgnac 3, level 2}

A total of two hundred and sixty tools on flakes were identified, mainly composed of side scrapers (57.5\%), and notches and denticulates (28.5\%). Composite tools are also present (notch with a side scraper combination, for example). Several active parts can be delimited on most of them. The dominant techno-type is mainly rectilinear and convex with linear cutting edges, and edge angles ranging between $35^{\circ}$ and $65^{\circ}$ (Fig. 7, C). Levallois flakes were mostly selected as blanks; thus, the aim of retouch may have been to increase the durability of these flakes. Punctiform and denticulate active parts are less represented, made on by-products from the main reduction processes and broken flakes. To sum up, retouched flakes are considered additional to the main unretouched production.

\subsection{4. $\quad \underline{\text { La Micoque, } \mathrm{L} 2 / 3}$}

Retouched flakes represent $1.4 \%$ of the total assemblage $(\mathrm{n}=54)$. Half of them are composed of side scrapers. Other diversified typological categories are also present: notches and denticulates, points or end scrapers. Retouch does not modify the initial morphology of the selected blanks and consists mainly of edge regularisation.

Most of the time, a single TFU T was identified on each piece. As for the unretouched production, linear cutting edges are observed (identified as additional). The main characteristics of this techno-type are the presence of a large linear edge opposed to a back. The angle of the cutting edge ranges between $35^{\circ}$ and $60^{\circ}$ and its morphology is rectilinear in plan and profile, sometimes a little convex. The cross-section morphology is biplanar, more rarely plano-convex. In addition to these techno-types, tools are produced with denticulate active parts and point-like active parts (sometimes associated with a linear cutting edge).

\subsection{5. $\quad$ Petit-Bost, level 2}

Tools on flakes are not abundant $(\mathrm{n}=40)$. They are essentially side scrapers $(60 \%)$, and notches and denticulates $(14 \%)$. The transformation of blanks is sometimes significant, with the presence of some side scrapers with Quina retouch. TFU Ts are manifested by linear cutting edges (rectilinear, sometimes convex or concave) (Fig. 7, D). This main techno-type can be divided into two edge angle sub-categories, which suggest distinct functional potentialities. A second group consists of point-like active parts (Fig. 7, D). Finally, some tools with denticulate active parts are present.

\subsection{6. $\quad$ Pech-de-l’Azé II, level 7}


Tools on flakes $(n=62)$ are essentially side scrapers $(n=28 ; 44.16 \%)$, and notches and denticulates $(n=14 ; 22.58 \%)$. End scrapers and perforators are more frequently represented than in the other lithic assemblages (respectively, $11.29 \%$ and $9.68 \%$ ). There is mainly a single TFU T on these retouched blanks. The dominant techno-type presents a linear cutting edge (rectilinear) opposed to a back (an actual back or a back corresponding to the butt - TFU R/P) (Fig. 7, E). Two groups with different edge angles were identified $\left(<50^{\circ}\right.$ and $\left.>50^{\circ}\right)$. Secondary techno-types consist of punctiform active parts (point-like areas) and denticulate parts. Tools on flakes are additional to the main unretouched productions.

\subsection{7. $\quad$ Combe Brune 2, level VIIa}

The tool count on flakes is very low, with only 24 pieces. Side scrapers dominate (more than half), followed by notches and denticulates. Linear active parts seem to have been the main aim, mainly rectilinear (with two categories of edge angles, $>50^{\circ}$ and $<50^{\circ}$ ) (Fig. 7, F). Punctiform and denticulate active parts are secondary. Here again, tools on flakes are additional to the main unretouched productions.

\subsubsection{Synthesis of morpho-functional analysis}

When typological categories are considered, tools on flakes are dominated by side scrapers in all sites, followed by notches and denticulates. An apparent homogeneity seems to emerge between sites based solely on typology. However, when techno-morphological characteristics are taken into consideration, two kinds of tool production emerge (Fig. 11):

- $\quad$ Level 7 of Orgnac 3: Point-like TFU Ts are prevalent, followed by linear edges and denticulated edges. The retouched category is complementary to flake production (linear edges).

- All the other sites: Linear cutting edge TFU Ts are predominant, followed by point-like edges and denticulate edges. This is the opposite situation, where the retouched category is additional to flake production.

\subsection{Shaping concepts}

\subsubsection{Orgnac 3 , level 7}

In this level, there are six bifaces and a single chopper in limestone managed by a few removals forming a rectilinear cutting edge in the distal zone (Fig. 10, D).

\subsubsection{Orgnac 3 , level 6}

Shaping chaînes opératoires are represented by bifaces, pebble tools and numerous shaping flakes $(\mathrm{n}=113)$. Four bifaces were discovered (three in flint and one in basalt) (Fig. 8, A, C). The basalt biface is very altered, rendering technological analysis difficult. Shaping is not systematised; shaping processes are alternant or face-after-face with a final shaping phase. Cortical areas subsist on all the bifaces and a natural back is maintained on one slab. In another case, a flake was selected as a blank for shaping. TFUs are point-like, associated in two cases with a linear cutting edge. Edge angles are sharp, comprised between $30^{\circ}$ and $40^{\circ}$. Microwear analysis identified macro-traces of longitudinal actions for two bifaces in flint (Viallet 2016). Some biface mobility is possible: the raw materials of the bifaces and shaping flakes are different. Moreover, the number of shaping flakes is not consistent with the few bifaces in this level.

Half of the pebble tool assemblage $(n=4)$ is composed of choppers and the other half of chopping-tools (in silicified limestone and basalt). A uniface in basalt is also present, with a rather similar shape to the biface in the same raw material. The active biface parts are represented by point-like areas associated with a linear edge, whereas linear cutting edges are sought after in other shaped pieces. We can add to this category a large flake from a limestone pebble, with potential utilisation scars on a rectilinear cutting edge opposed to a large butt. One triface was also identified (Fig. 9, C), as well as a mixed bifacial matrix (Fig. 10, B). 


\subsubsection{Orgnac 3, level 2}

Shaping systems are mainly represented by pebble tools (Fig. 10, C), consisting of equal proportions of choppers $(\mathrm{n}=10)$ and chopping-tools $(\mathrm{n}=10)$, associated with one uniface and five broken or unclear pieces (including chopper cores?). The selected blanks are oblong pebbles shaped on their shorter side by a few removals. The aim of shaping is linear cutting edges (rectilinear, convex), associated with a heavy weight. Cutting edges are robust, with angles between $70^{\circ}$ and $90^{\circ}$. Raw materials are different from the debitage: limestone, basalt and quartzite, suggesting a dichotomy in raw material economy.

Only two bifaces in flint were discovered, and they are quite different from those from the lower levels (Fig. 8, B). The base is large and remains cortical, and shaping processes comprise few removals, without regularisation in one case. Point-like active parts are intentionally shaped (one associated with a linear cutting edge), with different edge angles and morphologies (including one robust point of approx. $80^{\circ}$ and one of $30^{\circ}$ ). Microwear analysis was performed on the sharpest biface (Viallet, 2016b). Macro-wear resulting from cutting movements was identified on this biface.

\subsection{4. $\quad \underline{\text { La Micoque, } \mathrm{L} 2 / 3}$}

Evidence of shaping is very scarce, with 17 flakes from shaping and a single bifacial piece. The bifacial tool is a mixed matrix used for both the manufacture of a tool and the production of flakes (Fig. 10, A). There are two potential active areas (linear TFU T) opposed to a back (TFU R/P). The first TFU T is convex, with an edge angle of $65^{\circ}$, whereas the second is rectilinear with edge angles between $70^{\circ}$ and $80^{\circ}$. The two faces were shaped successively, one after the other, by invasive removals and with a minor terminal phase or regularisation.

\subsubsection{Petit-Bost, level 2}

Shaped productions are well represented in this layer with 20 pieces in flint. These include the production of some pebble tools but mostly of bifaces $(\mathrm{n}=17)$. A large uniface on Bergeracois flint flake was also discovered.

Bifaces are highly variable in shape and size, with diversified shaping techniques (alternant, face-after-face, etc.) (Fig. 8, D-F). A constant is the maintenance of a cortical area on the proximal part, corresponding to the possible prehensile part (TFU R/P). This is the richest lithic biface assemblage. Some pieces present re-sharpening, such as a notch.

As mentioned above, trifacial productions also exist (Fig. 9, B; Fig. 10, F). The trifacial tool is oriented toward the production of point-like TFU Ts, sometimes associated with a linear cutting edge. The TFU R/P is thus perpendicular or oblique, corresponding to the base or the back of the triface (third surface).

\subsubsection{Pech-de-l’Azé II, level 7}

Two pieces in flint can be described as mixed bifacial matrices. The other shaped pieces consist of two bifaces (in Senonian flint), four pebble tools (in Senonian flint and quartz) and a uniface (basalt). Linear active edges (rectilinear or convex TFU T) are sought after for all these categories; only one biface presents a punctiform active part (point-like TFU T associated with a cutting edge, with a robust edge angle of $86^{\circ}$ for the point and an associated robust notch). One biface is totally covered by removals with a shaped base (Fig. 8, G). The other is made from a flake, with invasive removals and some cortex remaining.

Apart from the uniface, all tools present a wide base (mainly cortical - TFU R/P) opposed to the active part.

\subsubsection{Combe Brune 2, level VIIa}

Shaping processes are represented by 11 pieces: bifaces and atypical bifacial pieces (n=8) - Fig. 8, H-G; Fig. 10, E), two pebble tools (one chopper and one chopping-tool) and a broken shaped piece. All the tools are in local flint (Bergeracois), except a chopper in quartz. Active parts are morphologically diversified. Linear cutting edges dominate (TFU T), but there are also punctiform parts (sometimes associated with a linear cutting edge) and denticulate TFU Ts. Some trifaces were also found (Fig. 9, A).

\section{Comparison}


In all the sites, the production of flakes is the main purpose of lithic technology, even if shaped tools are present (bifacial tools, trifacial tools and choppers/chopping-tools). At La Micoque for instance, LCTs are anecdotal. Wide variability also exists between bifacial productions. These differences may be due to the shapes or types of raw materials used for each site; large Bergeracois flint nodules for Combe Brune 2 and Petit-Bost, flint slabs for Orgnac 3 and Senonian nodules or pebbles for Pech-de-l'Azé II or La Micoque. Various knapping methods are employed such as S.S.D.A., Levallois, COFs (Cores-on-Flake) or Discoid. In both south-western and south-eastern France, ramified productions (Bourguignon et al. 2004) are identified in rich flint environments, illustrating specific and regional organisation of chaînes opératoires (discontinuity through knapping events).

It is difficult to relate differences in site strategies to the type or function of the site, in particular in the Dordogne area, as fauna is not preserved everywhere (for instance at Petit-Bost or Combe-Brune 2). The only significant feature may be the gathering of more diversified raw materials in the two cave sites (Orgnac 3 and Pech-de-l'Azé II). However, a high diversity of raw materials were also employed in level 2 at Orgnac 3, which can be considered as a partial open-air site, in front of a small shelter. The duration of occupation and the aspect of the habitat may have a significant impact on the composition of the lithic assemblage.

Specific data on knapping processes can be highlighted. Levallois productions were identified in all our site corpuses, except in levels 7 and 6 of Orgnac, at the bottom of the sequence, where only typo-Levallois products were identified. An interesting difference can be underlined in the Levallois method used. Moreover, in southwestern France, recurrent unipolar and bipolar methods were preferentially used, whereas recurrent centripetal methods were mostly used at Orgnac in south-eastern France. This difference in Levallois strategies is observed in other penecontemporaneous sites, and may prefigure differences between these two areas during the ensuing Late Middle Palaeolithic period (Moncel 2003; Bourguignon et al. 2008; Djema 2008; Brenet 2013; Carmignani et al. 2017).

The question of the processes leading to the emergence of the MP in these two southern areas is rather complex. We observe an increasingly standardised Levallois technology throughout the sequence at Orgnac 3, between MIS 9 and 8, and from typo-Levallois to real Levallois systems. Core volume is totally configured from the middle of the sequence onwards, fitting all Boëda's criteria (Boëda 1994). Whereas a gradual process may be identified at Orgnac 3, the situation is not that clear in Dordogne, as the sequences there do not comprise recurrent occupations. Comparisons with older sites in this area (e.g., before MIS 8) are required in order to observe the main processes.

\section{Discussion}

\subsection{Role of raw material management and site function}

Different patterns of the raw material economy can be highlighted (Perlès, 1980, 1991):

- At Orgnac 3, most of the raw materials are local slab flints but other rocks were also collected: flint pebbles and nodules, quartz, quartzite, limestone, basalt, sandstone and granite pebbles. There is a clear raw material dichotomy between flaking and shaping strategies. Flints were used for flaking and for biface shaping, whereas pebble tools are on the other raw materials. In south-western France, the only other site with similar disparate use of raw materials is Pech-de-l'Azé II, with flint, chalcedony, quartz, sandstone and basalt. Moreover, a specific flaking method (i.e., discoid) was applied to quartz.

- In the other sites in south-western France, flint and chalcedony are almost the exclusive raw materials, and were sometimes collected far from the site (e.g., Petit-Bost, $30 \mathrm{~km}$ ). There is no clear raw material economy, since only a few pieces in quartz were found, in addition to flint and chalcedony, and practically no other raw materials were used.

The main raw materials are local flints, identified by their microfossils and modules. At Orgnac, flint slabs from the Riparian basin of Barjac-Issirac were used in each level. In the sites of the Dordogne region, local Senonian flints were collected (La Micoque, Petit-Bost, Pech-de-l'Azé II) and the occupations were sometimes directly located on the outcrops (Combe Brune 2 upon Bergeracois flint). Some rarer flints or other raw materials (sandstone, quartz, basalt, etc.) were sometimes collected, but always in small quantities. 
Generally, raw materials were collected in a local or semi-local perimeter within a radius of $15 \mathrm{~km}$. Only one exception is observed at Petit-Bost where some Bergeracois flints were collected at $30 \mathrm{~km}$. They were introduced to the site as end products (tools) or cores.

The predominance of local procurement suggests limited territories of exploitation for lithic resources. However, the introduction and exportation of some pieces suggests mobility at the scale of the artefact (introduction of cores to be flaked or exports of tools etc.: Brenet et al., 2014) in small territories in relation perhaps either to the richness of the mineral environment (numerous available flint outcrops) or the type of occupation.

However, observations on the ratio of the import/export of tools and mobility patterns are limited by taphonomic processes and the macroscopic determination of the raw materials. Three features emerge from these results:

- Pattern 1: an in situ supply with occasional semi-local supplies (Combe Brune 2)

- Pattern 2: Almost exclusively local and semi-local supplies (0-15 km) (Orgnac 3, Pech-de-l'Aze II, La Micoque)

- $\quad$ Pattern 3: Local and semi-local supplies, associated with long-distance materials from a perimeter of 30 $\mathrm{km}$ (Petit-Bost). There does not appear to be an east-west distribution for these patterns, suggesting that there is no relationship with available raw material resources. Nor is there any clear chronological pattern.

These three categories can be applied to other sites. The first is typical of sites with very good-quality flint or with specific raw material procurement, such as flint workshops (Duran and Abelanet, 2004; Menras, 2009; Dawson et al., 2012; Brenet, 2013). This is also the case for open-air sites implanted directly on alluvial formations, such as the EMP and MP in the Hérault valley (ongoing study). The second pattern is less common in the Mediterranean area and can be observed at the site of Bau de l'Aubesier during MIS 7 and the sites of Ramandils and SaintMarcel during MIS 5 (Grégoire in Boutié et al., 2001; Moncel et al., 2004; Wilson and Browne, 2014; Carmignani et al., 2017). Pattern 3 is common, especially for Mousterian sites in both the Mediterranean area and the Aquitaine basin (Lebègue et al., 2010; Grégoire, 2012; Saos et al., accepted; Turq et al., 2017). Other EMP sites also show this trend, such as Payre and Lazaret Cave in south-eastern France (Grégoire in Lumley 2004; Moncel et al., 2019).

In sum, we do not observe clear chronological trends. All these patterns can be observed during the Early and Late Middle Palaeolithic. Site function is perhaps a better criterion for understanding this diversity of land use patterns. Moreover, these patterns cannot be related to the lithic technology employed on each site.

\subsection{Inherited versus innovative technical behaviours}

The southwest and southeast of France share a similar technological background: debitage-dominant assemblages (Levallois, algorithmic, Quina, etc.), associated with a small component of LCTs. Small flake production and ramified strategies are also among the major components of the technocomplexes. Mixed matrices are rare, but characteristic of most of the sites: bifacial, trifacial or notches/denticulates. These mixed matrices cannot be specifically linked to Lower Palaeolithic (LP) or MP industries but point rather to transitional complexes. Despite their similarities, differences also exist - for example, between the Levallois methods employed: recurrent unipolar and bipolar in Dordogne and recurrent centripetal in Ardèche. This may prefigure the regionalisation of these two areas, which is easily perceptible during the Late Middle Palaeolithic.

Considering their attributes, the studied sites can be classified as Early Middle Palaeolithic sites, characterised by the innovative and inherited technical practices detailed below.

\subsubsection{Innovative technical practices}

\subsubsection{Blank production by debitage and the emergence of Levallois debitage}

Debitage technologies can be classified into three categories: 
- Levallois-dominant: This concept is preponderant in level 2 of Orgnac 3 (beginning of MIS 8, circa 300 ky) and in level VIIa of Combe Brune 2 (MIS 7/6). Recurrent methods are mostly used, centripetal in level 2 at Orgnac 3 and unipolar/bipolar in level VIIa at Combe Brune 2, which distinguishes the two sites from each other. Some preferential cores and/or flakes were also found in both lithic assemblages.

- Algorithmic method-dominant: Methods such as SSDA, Quina or alternant productions are dominant in levels 6 and 7 of Orgnac 3 (MIS 9), Petit-Bost (MIS 9/8), and La Micoque (MIS 10/9). In general, such algorithmic methods are generally considered to be poorly predetermined, but that is not the case here. At Petit-Bost, the technology is geared towards products with a large back or a large platform (obtained by algorithmic and Quina debitages). In level L2/3 of La Micoque, flakes are highly normalised (elongated with a lateral back), obtained by unipolar/bipolar methods. Here, the apparent simplicity of technical gestures does not rule out specific needs or intentions.

- The case of Pech-de-l'Azé II: Specific methods on flakes predominate: Le Pucheuil-like methods on the thickness of flake-blanks (Delagnes 1992, 1993; Lazuen and Delagnes 2014) and Kombewa. Levallois debitage is also employed (observed on cores but mostly on flakes). Discoid methods were only applied to a specific raw material (quartz).

Debitage systems thus dominate the series. Between MIS 9 and 6 in the sites under consideration, a diversity of concepts can be observed, including recurrent systems: Levallois, cores-on-flakes or discoid. The discoid technology is different from Late Middle Palaeolithic technology: pseudo-Levallois points are not always the end products and exploitation sequences are shorter than in Late MP sites such as Champs-de-Bossuet (Bourguignon et al. 2000). Even when the three systems (Levallois, cores-on-flakes and discoid) were not used, flaking was the preferred way to produce blanks.

Levallois technology is dominant in two sites (Combe Brune 2, level VIIa and Orgnac 3 level 2). Recurrent methods are the most widely employed, although some lineal cores and flakes were observed. Levallois technology is also attested at La Micoque, Petit-Bost and Pech-de-l'Azé II, in lesser proportions.

At Orgnac 3, a gradual evolution towards full Levallois technology is visible over the sequence (Moncel 1999; Moncel et al. 2011, 2012), suggesting a local emergence. In Dordogne, the dates do not enable us to observe a local onset, due to the lack of multi-stratified occupations like those at Orgnac 3.

Recent studies describe the emergence of Levallois core technology in Europe as a mosaic pattern. In the Elbe area in Germany, Levallois technology may have been introduced with the arrival of Acheulean populations from the west during MIS 7 (Wiśniewski, 2014). A similar hypothesis has been proposed in Italy for sites in the Latium (Soriano and Villa 2017).

Our results confirm a progressive and local onset of the Levallois concept at Orgnac 3 in a context of centripetal recurrent methods (e.g., Moncel et al. 2011, 2012, 2020). Equally, a gradual emergence "in a context of unidirectional reduction of core volume" is proposed for the sites of Zwochau and Markkleeberg in Germany, dated between MIS 9 and MIS 8 (Picin 2018, p. 8). This observation is also valid for British sites and sites in Northern France and at a broader scale in north-central Europe (White and Ashton 2003; Bolton 2015; Hérisson et al. 2016a). At Etricourt-Manancourt, Levallois technology suggests a relationship between the Lower Palaeolithic level (MIS 9) and the EMP levels (from the MIS 7) (Hérisson et al. 2016b).

What are the factors responsible for this onset of the Levallois technologies? An emergence from bifacial technology has been proposed (Breuil and Keeley 1956; Bordes 1961; Copeland 1995; Tuffreau 1995; De-Bono and Goren-Inbar 2001; Lamotte and Tuffreau 2016), as well as an emergence from both flaking and shaping elements (Hopkinson 2001; White and Ashton 2003). According to these hypotheses, Levallois technologies would emerge from known elements during the Acheulean as innovative processes using existing technologies.

The abandonment of bifacial technology in favour of Levallois technology has also been interpreted in relation to the innovation and systematisation of hafting. This may have influenced technical systems, leading to the disappearance of bifacial technologies (Boëda 1997; Nicoud 2011). However, evidence of hafting is scarce during the European EMP, perhaps due to the lack of systematic microwear analyses (Mazza et al. 2006; Rots 2013). 
Recent studies demonstrate that recurrent methods produce a wide range of end products and propose the hypothesis that Levallois methods could represent an adaptive advantage for hominins ("the toolkit in the core": Shimelmitz and Kuhn, 2018 and references therein). This could explain the success of recurrent methods and not only of the "lineal one", particularly in southern European territories.

In conclusion, it appears that up until now, no clear explanation stands out from the others. Complexity is generated by diversified social, environmental and chronological contexts of expression and both local emergences and diffusion may be considered at local scales.

\subsubsection{Cores-on-flakes and recycling}

One of the most important characteristics of these lithic assemblages is the use of flakes as production matrices (cores-on-flakes/flaked-flakes). Specific methods on flakes represent more than $20 \%$ of the series of cores (such as recurrent and lineal Kombewa, Nahr-Ibrahim, etc.). But in reality, the proportion of flake matrices is much higher, since they were also used for Levallois, Quina or discoid flaking. This attests to clear ramified exploitation strategies (Bourguignon et al. 2004), since no double-patina pieces were identified (cf. recycling: Amick 2014). The aim of these productions was not only to obtain products of smaller size, although that was mostly the case. Indeed, in some sites, size reduction in comparison with cores on blocks is not systematic (La Micoque, L2/3). Rather, flakes with specific morpho-technical characteristics seem to be anticipated (such as biconvex edges in section). This particular economic behaviour constitutes a change with the Lower Palaeolithic where it is less common. The presence of COF or small flakes is on the other hand well known during the Late Lower Palaeolithic and Middle Palaeolithic (Geneste and Plisson 1996; Bourguignon et al. 2004; Dibble and McPherron 2006; Villaverde et al 2012; Rios-Garaizar et al 2015a; Vaquero et al 2015; Borel et al. 2017; Venditti et al. 2019).

The lithic assemblage where flake matrices are the most employed is undoubtedly level 2 of Orgnac 3, where more than 55\% of the cores are on flakes (Mathias 2016). There is a replication of the main flaking system (Levallois recurrent centripetal), but other specific methods, such as Kombewa (recurrent, lineal), or those applied to the dorsal face (Nahr-Ibrahim-like), are also observed. These micro-productions become clearly preponderant in the overlying layer (level 1 - more than 25,000 small flakes; Moncel et al. 2011).

Several explanations account for the use of flake matrices for debitage: raw material constraints (long distances or difficult access to raw materials, types of modules, raw material quality); economic organisation (linked to subsistence strategies); site function (e.g., specific activities linked to small productions); technical shortcut in Levallois productions, with increased convexities; a link with another major innovation: hafting; individual choice and/or individual technical competence; techno-cultural traditions.

In the studied sites here, raw material constraints cannot account for this use of flake matrices (abundance of raw materials, a large range of modules available in the environment). All the other factors may however be involved to varying extents. In all the studied sites, there is a lack of end products in comparison with cores-on-flakes. This may suggest a mobility of end products in hominin tool-kits. It can thus be argued that ramified production systems were planned strategies to meet a specific need. These strategies participate in a more structured and diversified range of production systems (structuring activities?), linked to the emergence of MP behaviours.

Double-patina flaked pieces are scarce in the studied assemblages, but other recycling phenomena have been highlighted at Combe Brune 2 and Orgnac 3. Discoid cores with percussion traces indicate their secondary use as hammers, as well as a flake bulb-retoucher in level 6 of Orgnac 3. Recycling has been recorded since the Oldowan and such behaviours have also been highlighted during the European MP (Claud et al. 2010; Thiebaut et al. 2010; Nieto-Marquez and Baena 2017).

\subsubsection{Tool management}

With regard to retouch techniques, an evolution is perceptible over time at Orgnac 3, probably linked to the evolution of flaking systems. In the lower levels (6 and 7), retouch is invasive, and covers and modifies initial flake morphology. By contrast, in level 2, retouch is thin, marginal and does not modify initial flake morphology. This can be correlated with the preponderance of Levallois technology, whereas SSDA methods are more widely 
employed in the other levels. In these lower levels, tool management is quite similar to what was observed in the Quina industries.

At all sites, shaped productions represent minor strategies employed to produce large tools. Bifaces and pebble tools (choppers, chopping-tools) are the most common pieces, although they only occur in small quantities. Some other atypical tools and unifaces are sporadically present in the series. Cleavers are totally absent. All the shaped pieces are technically and morphologically diversified in and between each lithic assemblage. However, some features may be highlighted. The bases of bifaces are typically cortical and thick, and may possibly have served as prehensile parts. Their final size and shape differ within and between sites. Morphologies are different from those of the MTA, which are mostly thin, totally shaped and plano-convex (Soressi 2002; Claud 2008), although some of the bifaces in this corpus have plano-convex cross-sections. The examination of biface edges shows that point-like tools, as well as linear edges, were intentionally shaped. The types of selected blanks are diversified in each assemblage (nodule, pebble, slab or cupule) but flint is the main raw material used. There is some evidence of resharpening, mainly at Petit-Bost. The only site without bifaces is La Micoque, although some flakes from shaping were uncovered.

Pebble tools are diversified and particularly well represented in level 2 of Orgnac 3. The manufacture of linear edges is the main purpose in all sites. Considering these tools as a whole, a wide assortment of specific activities was possible. Raw materials are diverse, such as basalt, quartz, quartzite and limestone.

\section{$\underline{\text { 6.2.1.4. Combined matrices }}$}

Combined matrices are one of the characteristics of these sites. They are found in several forms: core-like notches or denticulates, combined bifacial matrices and finally combined trifacial matrices.

- Core-like notches-denticulates: these are one of the characteristics of level 2 of Petit-Bost. They are flakes with large notches on the upper surface that can be similar to both a retouching and flaking phase. They represent a significant part of production matrices $(13.5 \%)$ and are integrated into more traditional flake production. Typical products are wider than long, with a peripheral edge and a very open striking platform (ventral surface).

- Bifacial combined matrices: these are present in L2/3 level of La Micoque, in level 7 of Pech-de-l'Azé II, as well as in level 6 of Orgnac 3, represented by one or two pieces. In La Micoque, no bifaces have been found, while in Pech-de-l'Azé II and Orgnac, bifacial shaping is used. These pieces have a mixed status with regard to flake tools, with a relationship of supplementary or functional complementarity. On this point, they are rather to be compared to bifaces because of their larger dimensions.

- Trifacial combined matrices: The trifacial concept was defined on the basis of industries from southwestern France (Boëda 1989; Boëda et al. 1990; Chevrier 2006). It was first identified during a review of levels 8 and 9 of Pech-de-l'Azé II, attributed to the southern Acheulean (Bordes 1971; Boëda 1989). The trifacial concept has only been identified in three of our series, in level 2 of Petit-Bost (where it is most frequent) and in level VIIa of Combe-Brune 2 and in level 6 of Orgnac 3. We distinguished between several methods: strict flaking, flaking/shaping and flaking/retouch (Mathias and Bourguignon 2019). Until recently, this production concept was poorly recognised.

\subsubsection{Inherited practices: persistence of ancient behaviours}

\subsubsection{Algorithmic methods}

In the studied sites, algorithmic productions (e.g., SSDA methods, Ashton 1992; Forestier 1993) continue to be employed. They are even clearly dominant in level L2/3 of La Micoque, level 2 of Petit-Bost and the lower levels of Orgnac 3

Many different methods are grouped under the SSDA label. This generates a high degree of difficulty in the comparison of industries, due to the high number and diversity of the recorded attributes. As in the case of level L2/3 of La Micoque, algorithmic methods do not induce the absence of normalisation of end products. In some ways, Quina reduction sequences can be considered as specific SSDA methods, with a lateralised replication of the algorithm, producing very similar end products (thick asymmetric flakes with a large open platform, with or 
without a cortical back: Bourguignon 1997). Quina is known during the early MIS 9/8 at Petit-Bost, and very similar debitages were observed at Payre (Baena et al. 2017).

\subsubsection{Shaping and LCTs}

Bifaces and unifaces from the studied sites present affinities with Lower Palaeolithic tools, in terms of their overall shape and production methods. Most of the time, direct hard percussion is employed, but there is also evidence of direct soft percussion in level 6 of Orgnac 3. However, proportions are still very low (the richest biface assemblage is level 2 of Petit-Bost, with 17 bifaces).

Differences in the role and structure of bifaces have been suggested for the Early Middle Palaeolithic (Villa 2009). During the Acheulean, bifaces would correspond to "biface-tools" and then to "biface blank-oftools", with different categories of tools made on their edges, such as scrapers, denticulates. They were often resharpened (Boëda et al. 1996). Techno-morpho-functional differences have also been identified (Soriano 2000; Nicoud 2011). This question remains complex and chronological frameworks for bifaces are not clear in Southern France on account of the very heterogeneous corpus.

Pebble tools (choppers, chopping-tools) are present in small proportions, except in level 2 of Orgnac 3, where specific activities may have been undertaken. These kinds of tools, which exist since the beginning of the Stone Age, are not in fact really diagnostic: occurrences are found until the Holocene. Their presence may merely suggest a particular range of activities.

\subsection{The Early Middle Palaeolithic in Southern France}

If one looks forward in the literature, the archaeological situation appears more complex. Acheulean-like industries coexist with clear Middle Palaeolithic industries. Thus, assemblages with a significant bifacial component are present until MIS 6 in both areas. In south-eastern France, clear MP industries are known from the beginning of MIS 8 with level 2 of Orgnac 3. It presents all the characteristics of the Levallois technocomplex associated with the Late Middle Palaeolithic (Faivre et al. 2017). Industries combining MP and a few Acheulean components (shaping) are also present during MIS 8/7 at Payre or la Baume-Bonne, for example (Gagnepain and Gaillard 2003; Notter 2007; Moncel 2008; Moncel et al. 2009; Baena et al. 2017). However, industries qualified as Acheulean with a significant bifacial component are present until MIS 6 at Lazaret Cave (Lumley 2004; Viallet 2016a, b).

The situation is quite similar in south-western France (Dordogne and surroundings). Acheulean-like industries with a dominance of bifacial shaping are present until MIS 6, such as at Barbas C' 3 base and Cantalouette 1 (Boëda et al. 1996; Brenet et al. 2008a; Brenet 2013). The Southern Acheulean (Acheuléen meridional) is a group of industries initially defined by F. Bordes from the lower levels of Combe-Grenal and Pech-de-l'Azé II (Bordes 1971) and is now considered as an Early Middle Palaeolithic form (Colonge et al. 2010; Turq et al. 2010). These industries are characterised by the dominance of various debitage methods, the presence of rare shaped pieces and a Trifacial concept of production (Boëda 1989; Turq et al. 2010). They are present from MIS 9/8 to 6 at Petit-Bost level 2, at Barbas C'4 lower and at Combe Brune 3, for example (Folgado et al. 2005; Chevrier 2006). During all that time, those industries coexisted with typical MP sites, such as Vaufrey Cave or different layers of Combe Brune 2 (Rigaud 1988; Brenet 2013; Hernandez et al. 2014).

Another region presents an important area of interest. The Acheulean from the Pyrenees-Garonne region is characterised by the production of large blanks, cleavers sensu stricto and discoid technology (Mourre and Colonge 2007; Turq et al. 2010). These industries apparently coexisted with Early Middle Palaeolithic ones (Jarry 1994; Jarry et al. 2007; Hernandez et al. 2012; Colonge et al. 2017, 2018). Some sites also present a combination of characteristics from the Acheulean and the MP, such as Raspide 2 or Horsarrieu 2 (Colonge et al. 2010; Brenet et al. 2016).

To sum up, three areas can be delineated in southern France: the south-eastern area (Rhône valley and surrounds), the Pyrenees-Garonne area and the south-western area (mostly the northern Aquitaine basin). In each region, between MIS 9 and 6, Acheulean, Middle Palaeolithic and combined assemblages coexisted (variously named "Upper Acheulean", Early Middle Palaeolithic or Southern Acheulean). This supplies us with a rich context 
for discussing technical traditions, influences and perhaps exchanges between hominin groups. If differences existed (perhaps accentuated due to raw material contexts?), these three areas follow a similar technological trajectory toward the Middle Palaeolithic. As regards exchanges between groups, it is argued that even in bifacial assemblages, such as Barbas C' 3 base and Lazaret Cave, evidence of Levallois technology also exists, and therefore so does the knowledge of this technology (Boëda et al. 1996; Lumley 2004).

The situation is different in Northern France, where Acheulean sites are attested until MIS 9, replaced by Early Middle Palaeolithic sites from MIS 8 onwards, but mostly in MIS 7 (Hérisson 2012; Locht et al. 2016). Bifiacial production is only dominant at two sites: Gouzeaucourt $(\mathrm{G}, \mathrm{H})$ and Longavesne, with no clear chronological framework (Soriano 2000; Hérisson et al. 2016a, b).

\subsection{In the European context}

The situation between Northern and Southern France reflects, to a certain extent, the situation in Northern and Southern Europe. Climatic conditions affected settlement dynamics, as there is no continuous occupation in several areas (as in more northerly areas, but also in the North-western Caucasus: Golovanova and Doronichev 2017).

Numerous similarities can be highlighted between Southern France and other Mediterranean areas, such as the Iberian Peninsula and Italy. In Spain, Acheulean and Early Middle Palaeolithic lithic technocomplexes coexisted for a long period, between MIS 10/9 until MIS 6, for instance at Gran Dolina, Cuesta de la Bajada, Bolomor or Arlanpe (Santonja and Pérez González 2006, 2010; Álvarez-Alonso 2012; Ollé et al. 2013; de la Torre et al. 2013; Santonja et al. 2014, 2016; Rios-Garaizar et al. 2015b; Sánchez Yustos and Díez Martin 2015). The presence of an Acheulean technocomplex with Large Cutting Tools identified in layer PM4 of Porto Maior during MIS 8/7 is a unique occurrence (Mendez-Quintas et al. 2018). In Italy, Middle Palaeolithic industries are observed, at least near Rome and at Cave dall'Olio, during MIS 9 (Fontana et al. 2013; Soriano and Villa 2017), but Acheulean industries persist until MIS 5e at Boccabianca (Silvestrini et al. 2001).

On the other hand, the situation in Northern France is the same as in Belgium and in Germany for AcheuleanEarly Middle Palaeolithic industry sequences, with a shift between MIS 9 and 8 (Cahen et al. 1985; Soriano 2000; Richter 2010, 2016; Di Modica and Pirson 2016; Van Baelen 2017). It is a little more balanced in Great Britain, with the persistence of Acheulean traditions until, but no later than, the EMP during MIS 8 (White et al. 2011; Bates et al. 2014).

In the north-western Caucasus, settlement is not continuous during the transition between the LP and MP (Golovanova and Doronichev 2017), thus an external arrival of populations using MP industries in response to environmental constraints has been suggested.

These differences in the lithic record may reflect the complexity of settlement dynamics in Western European territories during the second half of the Middle Pleistocene. However, data are still lacking in some areas (Portugal, Central Europe, the Netherlands and the Balkans), due to the absence of excavated sites or a sufficient chronological framework.

For Southern Europe, the question can be asked as to which factors impact the composition of lithic industries. Several proxies may play a role, such as the environmental context (raw material availability, climatic changes), site function, and hominin cognition or technocultural traditions. Environmental factors can be partly eliminated, as seen by the coexistence of different industries within the same long chronological period (MIS 9 to 6).

\section{Conclusion}

Lithic assemblages from the Early Middle Palaeolithic in south-western and south-eastern France present a combination of inherited and innovative technological practices. In all cases, knapping is oriented towards the production of blanks by debitage and shaping methods are scarce, but present. In this context, Levallois technology emerges from MIS 9 onwards and other diversified debitage methods are also used: on flakes, Algorithmic (Quina, S.S.D.A.) and more rarely Discoid. Cores-on-flakes represent an important part of production, probably highlighting a more accurate structuration in knapping activities through time and space. Combined matrices (mainly bifacial, Trifacial) could also be a characteristic of these assemblages. 
Levallois productions and bifaces are no longer the only discriminant factors for the interpretation of EMP sites. Middle Palaeolithic technical behaviours are characterised by a diversification in debitage methods and a certain normalisation of end products and tools, associated with a decrease in tools produced by shaping. The data presented in this study show that Early Middle Palaeolithic industries from major sites in both Ardèche and Dordogne are clearly MP, considering their diversity in terms of debitage methods and the spatiotemporal organisation of the chaînes opératoires. In contrast, shaped productions are more similar to those found in the Acheulean record than to those from the Late Middle Palaeolithic. Flake production is thus clearly related to the Middle Palaeolithic, yet some elements from the Acheulean background are combined with this production (algorithmic methods and a few shaped products). Consequently, the Lower to Middle Palaeolithic transition appears in these areas to be a result of gradual and asynchronous change over the period from MIS 9 to 6, with the probable coexistence of Late Acheulean and Early Middle Palaeolithic techno-complexes in several areas.

A gradual change can be perceived in particular in the sequence of Orgnac 3, where a probable local development of Levallois technology between MIS 9 and 8 has been identified. Although flaking was the most widely used solution to produce blanks in the lower levels, the emergence and use of Levallois technology throughout the sequence is accompanied by major changes in the lithic record. The most significant changes are the ramification of chaînes opératoires (branching strategies) and the decrease in blank modification (e.g., scrapers). The increase in Levallois technology is accompanied by a reduction in the size of the microproduction.

The Lower to Middle Palaeolithic transition in Southern France is thus a complex process, with early manifestations of the MP during MIS 9 and a continuation of Acheulean-like assemblages until MIS 6 (Boëda et al. 1996; Lumley 2004; Jarry et al. 2007; Bourguignon et al. 2008; Turq et al. 2010; Moncel et al. 2011, 2012; Brenet 2013). This observation is also applicable at a broader scale to Western Europe (Cahen et al. 1985; Soriano 2000; Richter 2010, 2016; White et al. 2011; Bates et al. 2014; Di Modica and Pirson 2016; Picin 2018; Van Baelen 2017), and in particular to the Mediterranean area (Silvestrini et al. 2001; Fontana et al. 2013; Santonja et al. 2014, 2016; Soriano and Villa 2017; Mendez-Quintas et al. 2018). Thus, a combination of several technocomplexes coexist between MIS 9 and 6 in Southern France and Europe. In the majority of industries, it is possible to discern a similar "pool of knowledge" (Baena et al. 2017). The emergence of MP technological behaviours appears to be due to a combination of factors, and is strongly linked to more standardised debitage productions (not always linked to Prepared Core Technologies) and tools on flakes, associated with a more structured organisation of the chaînes opératoires and activities (ramification, recycling, hafting?). Those shifts in the lithic record may be partly, but not solely due to increased hominin cognition. Adaptation to environments and cultural processes must also have played a key role. Shifts in technology are associated with major changes in other aspects of subsistence: regular use of fire and more structured hunting strategies. It is clear that during the second part of the Middle Pleistocene, complex settlement dynamics exist, due to adaptation to climate change or the arrival of new populations (Gamble and Roebroeks 1999; Hublin and Roebroeks 2009). Demography itself may also be a motor of change, influencing the mobility strategies of hunter-gatherers (Gallagher et al. 2019) and their traditions.

Differences are thus perceptible between the three main areas of Southern France, but it can be argued that they share a similar technological trajectory with Southern Europe throughout the Middle Palaeolithic.

Conflict of Interest: The authors declare that they have no conflict of interest.

\section{References}

Adler DS, Wilkinson KN, Blockey S, Mark DF, Pinhasi F, Schmidt-Magee BA, Nahapetyan S, Mallol C, Berna F, Glauberlan PJ, Raczynsli-Henk Y, Wales N, Frahm E, Jöris O, Macleod A, Smith VC, Cullen VL, Gasparuan B (2014) Early Levallois technology and the Lower to Middle Palaeolithic transition in the Southern Caucasus. Science 345(6204): 1609-1613.

Almeida F (2001) Cores, tools, or both? Methodological contribution for the study of carinated lithic elements: The Portuguese case. In: Hays MA, Thacker PT (eds) Questioning the Answers: Re-solving Fundamental Problems of the Early Upper Paleolithic. B.A.R. International Series 1005, pp 91-98.

Álvarez-Alonso D (2012) Fisrt Neanderthal settlements in northern Iberia: The Acheulean and the emergence of Mousterian technology in the Cantabrian region. Quaternary International 326-327: 288-306. 
Amick D (2014) Reflections on the Origins of Recycling: A Paleolithic perspective. Lithic Technology 39(1): 6469.

Ashton N (1992) The High Lodge flint industries. In: Ashton N, Cook J, Lewis SJ, Rose J (eds) High Lodge. Excavations by G. de Sieveking, 1962-8, and J. Cook, 1988. British Museum Press, pp 124-168.

Aureli D, Rocca R, Lemorini C, Modesti V, Scaramucci S, Milli S, Giaccio B, Marano F, Palombo MR, Contardi A (2016) Mode 1 or mode 2? "Small tools" in the technical variability of the European Lower Palaeolithic: the site of Ficoncella (Tarquinia, Lazio, central Italy). Quaternary International 393:169-184.

Baena Preysler J, Moncel M-H, Cuartero F, Chacón Navarro G, Rubio D (2017) Late Middle Pleistocene genesis of Neanderthal technology in Western Europe: The case of Payre Site (south-east France). Quaternary International 436(A): 212-338.

Bates MR, Wenban-Smith FF, Bello SM, Bridgland DR, Buck LT, Collins MJ, Keen DH, Leary J, Parfitt SA, Penkman K, Rhodes E, Ryssaert C, Whittaker JE (2014) Late persistence of the Acheulian in southern Britain in an MIS 8 interstadial: evidence from Harnham, Wiltshire. Quaternary Science Reviews 101: 159-176.

Bennett KD, Provan J (2008) What do we mean by 'refugia'? Quaternary Science Reviews, 27: 2449-2455.

Boëda, E., 1989. La conception trifaciale d'un nouveau mode de taille préhistorique. In: Bonifay E, Vandeermersch B (dir) Les premiers Européens, Actes du 114 ${ }^{\mathrm{ème}}$ congrès des sociétés savantes. Paris, Comité des Travaux Historiques et Scientifiques, pp 251-263.

Boëda E (1993) Le débitage discoïde et le débitage Levallois récurrent centripète. Bulletin de la Société préhistorique française 90: 392-404.

Boëda E (1994) Le concept Levallois : variabilité des méthodes. Monographie du CRA, 9, CNRS Editions.

Boëda E (2013) Techno-logique et Technologie. Une Paléo-histoire des Objets lithiques. Collection Préhistoire au Présent. Archéo-editions.com.

Boëda E, Geneste J-M, Meignen L (1990) Identification des chaînes opératoires lithiques du Paléolithique ancien et moyen. Paléo 2(1): 43-80.

Boëda E, Soriano S, Noël-Soriano S (2004) Fonction et fonctionnement d'un site à la fin du Pléistocène moyen. Le niveau acheuléen C'3 base de Barbas I (Creysse, Dordogne). In: Bodu P, Constantin C (dir) Approches fonctionnelles en préhistoire, Actes du XXVème Congrès préhistorique de France, Nanterre, 24-26 Novembre 2000. Société préhistorique française, Paris, pp 293-305.

Boëda E, Kerzavo B, Mercier N, Valladas H (1996) Barbas c'3base (Dordogne), une industrie bifaciale contemporaine des industries du Moustérien ancien : une variabilité attendue. Quaternaria Nova VI: 465-504.

Bolton L (2015) Assessing the origins of Levallois through Lower Palaeolithic core variation: A comparative study of Simple Prepared Cores in northwest Europe. Dissertation, University of Southampton.

Bordes F (1954) Les gisements du Pech-de-l'Azé (Dordogne). I : Le Moustérien de Tradition Acheuléenne. L'Anthropologie 58: 401-432.

Bordes F (1971) Observations sur l'Acheuléen des grottes en Dordogne. Munibe 23 1: 5-23.

Borel A, Dobosi V, Moncel M-H (2017) Neanderthal's microlithic tool production and use, the case of Tata (Hungary). Quaternary international 435: 5-20.

Bourguignon L (1997) Le Moustérien de type Quina : nouvelle définition d'une entité technique. Dissertation, Université de Paris X-Nanterre.

Bourguignon L, Ortega I, Lenoble A (2000) Processus de formation du site moustérien de Champs-de-Bossuet (Gironde)/Formation processes of the Mousterian site of Champs-de-Bossuet (Gironde, France). Paleo 14: 2-24.

Bourguignon L, Faivre J-Ph, Turq A (2004) Ramification des chaines opératoires : une spécificité du Moustérien ? Paleo 16: 41-61. 
Bourguignon L, Djema H, Bertran P, Lahaye C, Guibert P (2008) Le gisement saalien de Petit-Bost (Neuvic, Dordogne) : à l'origine du Moustérien d'Aquitaine ? In: Jaubert J, Bordes J-G, Ortega I. (org), Les sociétés du Paléolithique dans un grand Sud-Ouest : nouveaux gisements, nouveaux résultats, nouvelles méthodes, séances de la SPF, 24-25 novembre 2006, Bordeaux. Bulletin de la Société Préhistorique Française, mémoire XLVII de la SPF, pp 41-56.

Brenet M (2013). Variabilité et signification des productions lithiques au Paléolithique moyen ancien. L'exemple de trois gisements de plein-air du Bergeracois (Dordogne, France). B.A.R. International Series, 2548, Archaeopress.

Brenet M, Folgado M (2009) Relations techno-économiques entre débitage et façonnage sur les gisements du Paléolithique moyen ancien de Cantalouette 1 et Combe Brune 3 (Creysse, Dordogne). Rivista di Scienze Preistoriche LIX:49-62.

Brenet M, Folgado M, Guibert P, Lenoble A, Sellami F, Rios-Garaizar J, Vieillevigne É (2006) Cantalouette 1 (Creysse, Dordogne), Etude inter-disciplinaire de trois niveaux du Paléolithique ancien. Bergerac, R.N. 21 section nord. Rapport Final d'Opération, INRAP, SRA Aquitaine.

Brenet M, Folgado M, Lenoble A, Bertran P, Vieillevigne E, Guibert P (2008a) Interprétation de la variabilité technologique de deux industries du Paléolithique moyen ancien du Bergeracois : Cantalouette 1 et Combe Brune 3 (Creysse, Dordogne). In: Jaubert J, Bordes J-G, Ortega I (org), Les sociétés du Paléolithique dans un grand SudOuest : nouveaux gisements, nouveaux résultats, nouvelles méthodes, séances de la SPF, 24-25 novembre 2006, Bordeaux. Bulletin de la Société Préhistorique Française, mémoire XLVII de la SPF, pp 57-81.

Brenet M, Folgado M, Vigier S, Claud E, Bertran P, Lahaye C, Vieillevigne E, Guibert P, Leroy N (2008b) Etude inter-disciplinaire des niveaux paléolithiques de Combe Brune 2 (Creysse, Dordogne) - Bergerac, R.N. 21 section nord. Rapport Final d'Opération, INRAP, SRA Aquitaine, 254 p.

Brenet M, Bourguignon L, Colonge D, Folgado M, Jarry M, Lelouvier L-A, Mourre V, Turq A (2014) Les technocomplexes du début du Paléolithique moyen en Aquitaine septentrionale : complexité, complémentarité des productions de débitage et de façonnage et implications comportementales. In: Jaubert J (dir), Transitions, ruptures et continuité en Préhistoire, 2 - Paléolithique et Mésolithique. Actes du XXVII Congrès préhistorique de France, (Bordeaux-Les Eyzies, 31 mai-5 juin 2010), pp 81-101.

Brenet M., Claud E., Bertran P., Pasquet V., Kreutzer S. (2016). Contextes géoarchéologiques et chronologiques des sites du Paléolithique moyen ancien de Pomarez, de Serreslous et d'Horsarrieu 2. Rapport d'opération de fouille archéologique. INRAP, SRA Aquitaine, $225 \mathrm{p}$.

Cahen D, Haesaerts P, Watteyne D (1985) La nappe alluviale de Petit-Spiennes et le début du débitage Levallois dans la vallée de la Haine. Archaeologia Belgica I: 7-16. Carmignani L, Moncel M-H, Fernandes P, Wilson L (2017) Technological variability during the Early Middle Palaeolithic in Western Europe. Reduction systems and predetermined products at the Bau de l'Aubesier and Payre (South-East France). PLOS ONE 12 (6): e0178550

Chevrier B (2006) De l'Acheuléen méridional au technocomplexe trifacial : la face cachée des industries du Bergeracois. Apport de l'analyse technologique de l'industrie lithique de Barbas I C'4 sup (Creysse, Dordogne). Gallia Préhistoire 48: 207-252.

Chevrier B (2012) Les assemblages à pièces bifaciales au Pléistocène inférieur et moyen ancien en Afrique de l'Est eu au Proche-Orient. Nouvelle approche du phénomène bifacial appliquée aux problématiques de migrations, de diffusion et d'évolution locale. Dissertation, Université de Paris-Ouest Nanterre la Défense.

Claud E (2008) Le statut fonctionnel des bifaces au Paléolithique moyen récent dans le Sud-Ouest de la France. Etude tracéologique intégrée des outillages des sites de La Graulet, La Conne de Bergerac, Combe de Brune 2, Fonseigner et Chez-Pinaud/Jonzac. Dissertation, Université de Bordeaux I.

Claud E, Mourre V, Thiebaut C, Brenet M (2010) Le recyclage au Paléolithique moyen. Des bifaces et des nucléus utilisés comme percuteurs. Archéopages: 6-15. 
Colonge D, Jarry M, Delfour G, Fondeville C, Arnoux T, Berthet A-L (2010) De la transition paléolithique inférieur-moyen dans la vallée de la Garonne : l'Acheuléen supérieur de Raspide 2 (Blagnac, Haute-Garonne). Bulletin de la Société préhistorique française 107(2): 205-225.

Colonge D, Bertran P, Busseuil N, Castets A, Elizabeth Clark A, Claud E, Debenham N, Deschamps M, Folgado M, Fourloubey C, Hernandez M, Mangier C, Normand C, Pasquet V, Prodeo F, Redondo M, Rouzo P, Sellami F, Vigier S (2017) Bayonne, Avenue du Prissé. Une séquence paléolithique de plein-air sur les hauteurs de Bayonne. Rapport d'opération de fouille archéologique. INRAP GSO, SRA Aquitaine.

Colonge D, Brenet M, Busseuil N, Elizabeth Clark A, Claud E, Debenham N, Deschamps M, Folgado M, Garon H., Geis L., Hernandez M, Mangier C, Matilla V., Normand C, Pasquet V, Rechin F., Redondo M, Rouzo P, Sellami F., Vigier S. (2018). Bayonne, Chemin de Jupiter, un nouveau jalon pour le Paléolithique de plein-air du plateau de Saint-Pierre-d'Irube. Rapport d'opération de fouille archéologique. INRAP GSO, SRA Aquitaine.

Combier J (1967) Le Paléolithique de l'Ardèche dans son cadre paléoclimatique. Publication de l'Institut de Préhistoire de Bordeaux, Mémoire 4.

Creswell R (1996) Prométhée ou Pandore ? Propos de technologie culturelle. Editions Kimé.

Dauvois M (1976) Précis de dessin dynamique et structural des industries lithiques préhistoriques. Fanlac.

Debard E (1987) Le Quaternaire du Bas-Vivarais : dynamique sédimentaire, paléoclimatologie et chronologie d'après l'étude sédimentologique des remplissages d'avens, de porches, de grottes et d'abris-sous-roches. Comparaison avec le Velay oriental. Dissertation, Université de Lyon I.

Debénath A, Dibble HL (1994) Handbook of Paleolithic Typology: Lower and Middle Paleolithic of Europe. University Museum, University of Pennsylvania, Philadelphia.

Delagnes A (1992) L’organisation de la production lithique au Paléolithique moyen. Approche technologique à partir de l'industrie de la Chaise de Vouthon en Charentes. Dissertation, Université Paris X.

Delagnes A (1993) Un mode de production inédit au Paléolithique moyen dans l'industrie du niveau 6E du Pucheuil (Seine-Maritime). Paléo 5: 111-120.

Delpech F, Geneste J-M, Rigaud J-Ph, Texier J-P (1995) Les industries antérieures à la dernière glaciation en Aquitaine septentrionale : chronologie, paléoenvironnements, technologie, typologie et économie de subsistence. Paléo supplément: 133-163.

Detrain L, Bats J-Ch, Bertran P, Colonge D, Fourloubey Ch, Grigoletto F, Lenoble A, Lhomme V (2005) La Croix de Canard (Neuvic-sur-l'Isle, Dordogne). DFS de fouille, A 89 section 2.3, INRAP - Direction interrégionale Grand Sud-Ouest.

Dibble H,Bernard M (1980) A comparison of basic edge angle measurement techniques. American Antiquity 45: $857-865$.

Dibble H, McPherron S (2006) The missing Mousterian. Current Anthropology 47(5): 777-803.

Di Modica C, Pirson S (2016) The Lower to Middle Palaeolithic Transition and the onset of Prepared Core Technologies in Belgium. Quaternary International 411 (B): 95-107.

Djema H (2008) Le Paléolithique moyen ancien de la Corniche cantabrique et du Bassin aquitain ou le phénomène culturel des premiers néandertaliens. Analyse techno-économique comparative des gisements cantabriques et périgourdins. Dissertation, Université Paris I/Panthéon-Sorbonne.

Donnart K (2010) L'analyse des unités techno-fonctionnelles appliquée à l'étude du macro-outillage néolithique. L'Anthropologie 114 (2): 179-198.

Faivre J-Ph (2011) Organisation techno-économique des systèmes de production dans le Paléolithique moyen récent du nord-est aquitain. BAR International Series 2280.

Faivre J-Ph, Gravina B, Bourguignon L, Discamps E, Turq A (2017) Late Middle Paleolithic technocomplexes (MIS5-3) in the northeastern Aquitaine Basin: Advances and challenges. Quaternary International 433 (B): 116131. 
Falguères C, Bahain J-J, Saleki H (1997) U-Series and ESR Dating of Teeth from Acheulian and Mousterian Levels of La Micoque (Dordogne, France). Journal of Archaeological Science 24: 537-545.

Fernandes P (2012) Itinéraires et transformations du silex : une pétroarchéologie refondée, application au Paléolithique moyen. Dissertation, Université de Bordeaux 1.

Fernandes P, Raynal J-P, Moncel M-H (2008) Middle Palaeolithic raw material gathering territories and human mobility in the southern Massif Central, France: first results from a petro-archaeological study on flint. Journal of Archaeological Science 35 (8): 2357-2370.

Fernandes P, Raynal J-P, Tallet P, Tuffery C, Piboule M, Séronie-Vivien M, Séronie-Vivien MR, Turq A, Morala A, Affolter J, Millet D, Bazile F, Schmidt P, Foucher P, Delvigne V, Liagre J, Gaillot S, Morin A, Moncel M-H, Granier J-F, Léandri-Bressy C (2012) Le silex du Bergeracois : état de la question. In: Bertran P, Lenoble A (dir) Quaternaire continental d'Aquitaine : un point sur les travaux récents, Excursion AFEQ-ASF en Aquitaine du 30 mai au 1er juin 2012, pp 22-34.

Folgado M, Brenet M, Sellami F, Bertran P (2005) Economie de façonnage et de débitage sur le gisement du Paléolithique ancien de Combe Brune 3 (Creysse, Dordogne), Bergerac, R.N. 21, section nord. Rapport Final d'Opération, INRAP, SRA Aquitaine.

Fontana F, Moncel M-H, Nenzioni G, Onorevoli G, Peretto C, Combier J (2013) Widespread diffusion of technical innovations around 300,000 years ago in Europe as a reflection of anthropological and social transformations? New comparative data from the western Mediterranean sites of Orgnac (France) and Cave dall'Olio (Italy). Journal of Anthropological Archaeology 32 (4): 478-498.

Forestier H (1993) Le Clactonien : mise en application d'une nouvelle méthode de débitage s'inscrivant dans la variabilité des systèmes de production lithique du Paléolithique ancien. Paléo 5: 53-82.

Forsten A, Moigne A-M (1998) The horse from the middle Pleistocene of Orgnac 3 (Ardèche, France). Quaternaire 9 (4): 315-323.

Frick JA, Herkert K (2014) Lithic Technology and Logic of Technicity. Mitteilungen der Gesellschaft für Urgeschichte 23: 129-172.

Frouin M, Lahaye C, Hernandez M, Mercier N, Guibert P, Brenet M, Folgado-Lopez M, Bertran P (2014) Chronology of the Middle Palaeolithic open-air site of Combe Brune 2 (Dordogne, France): a multi luminescence dating approach. Journal of Archaeological Science 52: 524-534.

Gaillard C (1982) L'industrie lithique du Paléolithique inférieur et moyen de la grotte de Coupe-Gorge à Montmaurin (Haute-Garonne). Gallia Préhistoire 25: 79-105.

Gallagher E, Shennan S, Thomas MG (2019) Food Income and the Evolution of Foragers Mobility. Scientific Reports 9: 5438.

Gagnepain J, Gaillard C (2003) La grotte de la Baume Bonne (Quinson, Alpes de Haute-Provence): synthèse chronostratigraphique et séquence culturelle d'après les fouilles récentes (1988-1997). In: La grotte de la BaumeBonne (Quinson, Alpes de Haute-Provence): synthèse chronostratigraphique et séquence culturelle d'après les fouilles récentes (1988-1997). John and Erica Hedges Ltd., pp 73-86.

Gamble C, Roebroeks W (1999) The Middle Palaeolithic occupation: A point of inflection. In: Roebroeks W, Gamble C (eds), The Middle Palaeolithic occupation of Europe. University of Leiden, pp 3-22.

Garreau S (2000) Etude technologique de l'industrie lithique acheuléenne du site des Pendus (Creysse, Dordogne). In: Boëda E, Guillomet-Malmassari V (dir), Des comportements techniques dans la préhistoire, actes de la Table Ronde de Nanterre. Ateliers 20, pp 7-28.

Gauthier A (1992) Paléoenvironement du pléistocène moyen dans le sud de la France, Apport et limite de l'analyse pollinique de trois sites préhistoriques : Caune de l'Arago, Orgnac 3, grotte du Lazaret. Dissertation, Muséum National d'Histoire Naturelle. 
Geneste J-M (1985) Analyse lithique d'industries moustériennes du Périgord : une approche technologique du comportement des groupes humains au Paléolithique moyen. Dissertation, Université de Bordeaux I.

Geneste J-M, Plisson H (1996) Production et utilisation de l'outillage lithique dans le moustérien du sud-ouest de la France. Les Tares à Sourzac, Vallée de l'Isle, Dordogne. Quaternaria nova 6: 343-367.

Golovanova LV, Doronichev VB (2017) The dynamics of stone industry transformation at the interface of lower and Middle Paleolithic in the Northwestern Caucasus. Quaternary International 428: 26-48.

Grün R, Stringer C-B (1991) ESR dating and the evolution of modern humans. Archaeometry 33: 153-199.

Grün R, Mellars P, Laville H (1991) ESR chronology of a 100000 year archaeological sequence at Pech de l'Azé II, France. Antiquity 65: 544-551.

Grégoire, S., 2012. Nature et évolution de l'organisation territoriale des populations paléolithiques du bassin méditerranéen. Unpublished habilitation thesis (HDR), Université de Perpignan Via Domitia, Tome 1, 197 p.

Hérisson D (2012) Etude des comportements des premiers Néandertaliens du Nord de la France. Les occupations saaliennes des gisements de Biache-Saint-Vaast et de Therdonne. Dissertation, Université des Sciences et Technologies de Lille.

Hérisson D, Brenet M, Cliquet D, Moncel M-H, Richter J, Scott B, Van Baelen A, Di Modica K, De Loecker D, Ashton N, Bourguignon L, Delagnes A, Faivre J-Ph, Folgado-Lopez M, Locht J-L, Pope M, Raynal J-P, Roebroeks W, Santagata C, Turq A, Van Peer P (2016a). The emergence of the Middle Palaeolithic in north-western Europe and its southern fringes. Quaternary International 411: 233-283.

Hérisson D, Coutard S, Goval E, Locht J-L, Antoine P, Chantreau Y, Debenham N (2016b) A new key-site for the end of the Lower Palaeolithic and the onset of Middle Palaeolithic at Etricourt-Manancourt (Somme, France). Quaternary International 409(B): 73-91.

Hernandez M, Mercier N, Bertran P, Colonge D, Lelouvier L-A (2012) Premiers éléments de datation des industries du Pléistocène moyen (Acheuléen - Paléolithique moyen ancien) de la région pyrénéo-garonnaise : une approche géochronologique pluri-méthodes (TL, OSL et TT-OSL). Paleo 23: 155-170.

Hernandez M, Mercier N, Rigaud J-Ph, Texier J-P, Delpech F (2014) A revised chronology for the grotte Vaufrey (Dordogne, France) based on TT-OSL dating of sedimentary quartz. Journal of Human Evolution 75: 53-63.

Hublin J-J, Roebroeks W (2009) Ebb and flow or regional extinctions? On the character of Neandertal occupation of northern environments. Comptes Rendus Palevol 8 5: 503-509.

Inizan M-L, Reduron M, Roche H, Tixier J (1995) Technologie de la pierre taillée. Préhistoire de la pierre taillée. t. 4, C.R.E.P.

Jacobs Z, Jankowski NR, Dibble HL, Goldberg P, McPherron SP, Sandgathe D, Soressi M (2016) The age of three Middle Palaeolithic sites: Single-grain optically stimulated luminescence chronologies for Pech de l'Azé I, II and IV in France. Journal of Human Evolution 95: 80-103.

Jarry M (1994) Etude techno-typologique du site d'Esclignac à Montmaurin (Haute-Garonne). Master thesis, Université de Toulouse le Mirail - EHESS.

Jarry M (2010) Les groups humains du Pléistocène moyen et supérieur en Midi toulousain : contextes, ressources et comportements entre Massif Central et Pyrénées. Dissertation, Université de Toulouse le Mirail.

Jarry M, Colonge D, Lelouvier L-A, Mourre V (dir.) (2007) Les Bosses (Lamagdelaine, Lot, France) : un gisement paléolithique moyen antérieur à l'avant-dernier Interglaciaire sur la moyenne terrasse du Lot. Société Préhistorique Française, «travaux », 7.

Jaubert J, Servelle C (1996) L'Acheuléen dans le bassin de la Garonne (région Midi-Pyrénées): état de la question et implications. In: Tuffreau A (dir) L'Acheuléen dans l'ouest de l'Europe, Actes du colloque international de Saint-Riquier, 6-10 juin 1989. Publications du CERP, 4,pp 77-108. 
Jeannet M (1981) Les rongeurs du gisement acheuléen d'Orgnac 3 (Ardèche). Bulletin de la Société Linnéenne de Lyon 50: 49-71.

Joly de R (1947) Hypothèse sur la formation de l'Aven d'Orgnac (Ardèche). La Nature 3139: 209-214.

Lahaye C (2005) Nouveaux apports de la thermoluminescence à la chronologie du Paléolithique dans le Sud-Ouest de la France. Etudes en milieux hétérogènes et en présence de déséquilibres radioactifs dans les séries de l’Uranium. Dissertation, Université de Bordeaux III Montaigne.

Langlois A (2004) Au sujet du Cheval de La Micoque (Dordogne) et des comportements humains de subsistance au Pléistocène moyen dans le Nord-Est de l'Aquitaine. Dissertation, Université de Bordeaux.

Langlois A (2005) Le cheval du gisement Pléistocène moyen de La Micoque (Les Eyzies-de-Tayac, Dordogne) : Equus mosbachensis micoquii nov. ssp. Paléo 17: 73-110.

Lazuén T, Delagnes A (2014) Lithic tool management in the Early Middle Paleolithic: an integrated technofunctional approach applied to Le Pucheuil-type production (Le Pucheuil, northwestern France). Journal of Archaeological Science 52: 337-353.

Lepot M (1993) Approche techno-fonctionnelle de l'outillage moustérien. Essai de classification des parties actives en termes d'efficacité technique. Application de la couche M2e sagittale du grand abri de la Ferrassie (fouille Henri Delporte). Master thesis, Université Paris X-Nanterre, Nanterre.

Leroi-Gourhan A (1964) Le geste et la parole. Tome 1 : Technique et langage. Albin Michel.

Locht J-L, Hérisson D, Goval E, Cliquet D, Huet B, Coutard S, Antoine P, Feray P (2016) Timescales, space and culture during the Middle Palaeolithic in northwestern France. Quaternary International 411: 129-148.

Lumley de H (Dir.) (2004) Le sol d'occupation acheuléen de l'unité archéostratigraphique UA 25 de la grotte du Lazaret. Edisud, Nice.

Malinsky-Buller A (2016) Lost and found: Technological trajectories within Lower/Middle Paleolithic transition in Western Europe, North of the Pyrenees. Quaternary International 409(B): 104-148.

Mathias C (2016) After the Lower Palaeolithic: lithic ramification during the early Middle Palaeolithic of Orgnac 3, layer 2 (Ardèche, France). Quaternary International 411(B): 193-201.

Mathias C, Bourguignon L (2019) Une nouvelle utilisation du concept Trifacial durant une phase ancienne du Paléolithique moyen de la vallée de l'Isle: le niveau 2 de Petit-Bost (Neuvic, Dordogne). Bulletin de la Société Préhistorique Française 116 (3): 423-454.

McPherron S.P (Ed.) (2007) Tools versus Cores. Alternative Approaches to Stone Tool Analysis. Cambridge Scholars Publishing, Newcastle.

Méndez-Quintas E, Santonja M, Pérez-González A, Duval M, Demuro L, Arnols LJ (2018) First evidence of an extensive Acheulean large cutting tool accumulation in Europe from Porto Maior (Galicia, Spain). Scientific Reports 8, 3082:13 p.

Michel V, Shen G, Shen, CC, Fornari N, Verati C, Gallet S, Sabatier D (2011) Les derniers Homo heidelbergensis et leurs descendants les néandertaliens : datation des sites d'Orgnac 3, du Lazaret et de Zafarraya. Comptes Rendus Palevol 10: 577-587.

Michel V, Shen G, Shen CC, Wu CC, Verati C, Gallet S, Moncel M-H, Combier J, Khatib S, Manetti M (2013) Application of U/Th and 40Ar/39Ar Dating to Orgnac 3, a Late Acheulean and Early Middle Palaeolithic Site in Ardèche, France. PLOS ONE 8 12: 17 p.

Moigne A-M, Moncel M-H (2005) Données nouvelles sur les restes fauniques et lithiques dans différents niveaux d'occupation du site d'Orgnac 3 (Ardèche, sud-est de la France) : types d'occupation. In: Molines N, Moncel MH, Monnier J-L (eds.) Les Premiers peuplements en Europe. BAR International Series 1364, pp. 215-226.

Moncel M-H (1999) Les assemblages lithiques du site Pléistocène moyen d'Orgnac 3 (Ardèche, Moyenne vallée du Rhône, France). ERAUL 89. 
Moncel M-H, Combier J (1992) L'exploitation de l'espace et les matières premières à Orgnac 3. Bulletin de la Société préhistorique française, Études et Travaux: 1-14.

Moncel M-H (Dir.) (2008) Le site de Payre. Occupations humaines dans la vallée du Rhône à la fin du Pléistocène moyen et au début du Pléistocène supérieur. Société préhistorique française, mémoire XLVI.

Moncel M-H, Moigne A-M, Combier J (2005) Pre-Neandertal behaviour during isotopic stage 9 and the beginning of stage 8. New data concerning fauna and lithics in the different occupation levels of Orgnac 3 (Ardèche, SouthEast France). Journal of Archaeological Science 32: 1263-1301.

Moncel M-H, Chacón Navarro MG, Coudenneau A, Fernandes P (2009) Points and convergent tools in the European Early Middle Paleolithic site of Payre (SE, France). Journal of Archaeological Science 36: 1882-1909.

Moncel M-H, Moigne A-M, Sam Y, Combier J (2011) The Emergence of Neanderthal Technical Behavior: New evidence from Orgnac 3 (Level 1, MIS 8), Southeastern France. Current Anthropology 52 (1): 37-75.

Moncel M-H, Moigne A-M, Combier J (2012) Towards the Middle Palaeolithic in Western Europe: the case of Orgnac 3 (southeastern France). Journal of Human Evolution 63: 103-124.

Moncel M-H, Fernandes P, Willmes M, James H, Grün R (2019) Rocks, teeth, and tools: New insights into early Neanderthal mobility strategies in South-Eastern France from lithic reconstructions and strontium isotope analysis. PLOS ONE: doi.org/10.1371/journal.pone.0214925

Moncel M-H., Ashton N., Arzarello M., Fontana F., Lamotte A., Scott B., Muttillo B., Berruti B., Nenzioni G., Tuffreau A., Peretto C. 2020. An Early Levallois core technology between MIS 12 and 9 in Western Europe? Journal of Human Evolution 139. In press.

Morala A (2017) Les silicifications des bassins versants de la Dordogne et de la Vézère : évaluation des ressources lithologiques et implications archéologiques. Paléo numéro spécial.

Mourre V (2003a) Implications culturelles de la technologie des hachereaux. Dissertation, Université Paris XNanterre.

Mourre V (2003b) Discoïde ou pas discoïde ? Réflexions sur la pertinence des critères techniques définissant le débitage discoïde. In: Peresani M (ed) Discoid Lithic Technology. BAR International Series 1120, Oxford, pp 118.

Mourre V, Colonge D (2007) Et si l'Acheuléen méridional n'était pas là où on l'attendait ? In: Un siècle de construction du discours scientifique en préhistoire, Avignon 21-25 septembre 2004, Congrès du centenaire de la SPF 3, pp 68-78.

Nicoud E (2011) Le phénomène acheuléen en Europe occidentale : approche chronologique, technologie lithique et implications culturelles. Dissertation, Université de Provence Aix-Marseille III - Universita degli studi di Roma La Sapienza.

Nieto Feliner G (2011) Southern European glacial refugia: A tale of tales. Taxon 60 2: 365-372.

Nieto-Marquez IO, Baena Preysler J (2017) Did stones speak about people? Flint catchment and Neanderthal behaviour from Area 3 (Cañaveral, Madrid-Spain). Quaternary International 435: 144-163.

Ollé A., Mosquera M., Rodríguez A, de Lombera-Hermida A, García-Anton MD, García-Medrano P, Luna P, Menéndez L, Navazo M, Terradillos M, Gargalló A, Márquez B, Sala R, Carbonell E (2013) The Early Middle Pleistocene technological record from Sierra de Atapuerca (Burgos, Spain). Quaternary International 295: 138167.

Owen WE (1938) The Kombewa culture, Kenya Colony. Man 38 218: 203-205.

Pelegrin J (1995) Technologie lithique : le Châtelperronien de Roc-de-Combe (Lot) et de La Côte (Dordogne). Cahiers du Quaternaire, CNRS Editions.

Peresani M (1998) La variabilité du débitage discoïde dans la grotte de Fumane (Italie du Nord)/The variability of discoid production at the grotte de Fumane. Paléo 10(1): 123-146. 
Picin A (2018) Technological adaptation and the emergence of Levallois in Central Europe: new insight from the Markkleeberg and Zwachau open-air sites in Germany. Journal of Quaternary Science, 33(3): 300-312.Picin A, Peresani M, Falguères C, Gruppioni G, Bahain J-J (2013) San Bernardino Cave (Italy) and the appearance of Levallois technology in Europe: results of radiometric and technological reassessment. PLOS One 8: p. e76182.

Prat F (1968) Recherches sur les Equidés pléistocène en France. Dissertation, Faculté des Science de Bordeaux.

Raynal J-P (Dir.) (2007) La grotte de Sainte-Anne I : Sinzelles, Polognac, Haute-Loire. Le Paléolithique moyen de l'unité J1. Les Dossiers de l'Archéo-Logis 3.

Richter J. (2010) When did the Middle Paleolithic begin? In: Conard NJ, Richter J (Eds.) Neanderthal lifeways, Subsistence and Technology. One Hundred Fifty Years of Neanderthal Study, Vertebrate Paleobiology and Paleoanthropology Series, Dordrecht, Heidelberg, London, New-York, pp 7-14.

Richter J (2016) Leave at the height of the party: a critical review of the Middle Paleolithic in Western Central Europe from its beginning to its rapid decline. Quaternary International 411: 107-128.

Rigaud J-Ph (Dir.) (1988) La Grotte Vaufrey: paléoenvironnements, chronologie, activités humaines. Mémoires de la Société Préhistorique Française 19.

Rios-Garaizar J, Eixea A, Villaverde V (2015a) Ramification of lithic production and the search of small tools in Iberian Peninsula Middle Paleolithic. Quaternary International 361: 188-199.

Rios-Garaizar J, Maidagan DG, Gómez-Olivencia A, Iriarte E, Arceredillo-Alonso D, Iriarte-Chiapusso MJ, Garcia-Ibaibarriaga N, García-Moreno A, Gutierrez-Zugasti I, Torres T, Aranburu A, Arriolabengoa M, Bailón S, Murelaga X, Ordiales A, Ortiz JE, Rofes J, Pedro ZS (2015b) Short-term Neandertal occupations in the late Middle Pleistocene of Arlanpe (Lemoa, northern Iberian Peninsula). Comptes Rendus: Palevol 14: 233-244

Rocca R (2016) First settlements in Central Europe: between originality and banality. Quaternary International 409(B): 123-221.

Rocca R, Abbruzzes C, Aureli D (2016) European Acheuleans: Critical perspectives from the East. Quaternary International 411: 402-411.

Rosendahl G (2006) Les couches supérieures de la Micoque (Dordogne). Paléo18: 161-192.

Sam Y, Moigne A-M (2011) Rôle des Hommes et des carnivores dans l'accumulation osseuse des niveaux profonds d'Orgnac 3 (Ardèche, France). In: Brugal J-Ph, Gardeisen A, Zucker A (eds) Prédateurs dans tous leurs états. Evolution, Biodiversité, Interactions, Mythes, Symboles. Editions A.O.D.C.A., pp 64-83.

Sánchez Yustos P, Diez Martín F (2015) Dancing to the rhythms of the Pleistocene? Early Middle Paleolithic population dynamics in NW Iberia (Duero Basin and Cantabrian Region). Quaternary Science Reviews 121: 7588.

Santonja M, Pérez-González A (2006) La industria lítica del miembro estratigráfico medio de Ambrona (Soria, España) en el contexto del Paleolítico antiguo de la Península Ibérica. Zephyrus 59: 7-20.

Santonja M, Pérez-González A, (2010) Mid-Pleistocene Acheulean industrial complex in the Iberian Peninsula. Quaternary International 223(4): 154-161.

Santonja M, Pérez-González A, Domínguez-Rodrigo M, Panera J, Rubio-Jara S, Sesé C, Soto E, Arnold LJ, Duval M, Demuro M, Ortiz JE, de Torres T, Mercier N, Barba R, Yravedra J (2014) The Middle Paleolithic site of Cuesta de la Bajada (Teruel, Spain): a perspective on the Acheulean and Middle Paleolithic technocomplexes in Europe. Journal of Archaeological Science 49: 556-571.

Santonja M, Pérez-González A, Panera J, Rubio-Jara S, Méndez-Quintas E (2016) The coexistence of Acheulean and Ancient Middle Palaeolithic techno-complexes in the Middle Pleistocene of the Iberian Peninsula. Quaternary International 411 (B): 348-377.

Séronie-Vivien M, Séronie-Vivien M-R (1987) Les Silex du Mésozoïque nord-aquitain. Approche géologique de l'étude des silex pour servir à la recherche préhistorique. Supplément au tome XV, Bulletin de la Société Linéenne de Bordeaux. 
Silvestrini M, Bassetti M, Boscato P, Coltorti M, Esu D, Lemorini C, Magnatti M, Peresani M, Rossetti M (2001) An Acheulean site of the last interglacial at Boccabianca (Cupra Marittima, Marche). Rivista di Scienze Preistoriche, LI: 21-71.

Solecki RL, Solecki RS (1970) A new secondary flaking technique at the Nahr-Ibrahim cave site, Lebanon. Bulletin du Musée de Beyrouth 23: 137-142.

Soressi M (2002) Le Moustérien de tradition acheuléenne du Sud-Ouest de la France. Discussion sur la signification du faciès à partir de l'étude comparée de quatre sites : Pech-de-l'Azé I, Le Moustier, la Rochette et la grotte XVI. Dissertation, Université de Bordeaux I.

Soressi M, Rendu W, Texier P-J, Claud E, d'Errico F, Laroulandie V, Maureille B, Niclot M, Schwortz S, Tillier A-M (2008) Pech-de-l'Azé I (Dordogne, France) : un nouveau regard sur un gisement moustérien de tradition acheuléenne connu depuis le XIXème siècle. In: Jaubert J, Bordes J-G, Ortega I (eds) Les sociétés Paléolithiques d'un grand Sud-Ouest : nouveaux gisements, nouvelles méthodes, nouveaux résultats. Actes des journées décentralisées de la SPF des 24-25 novembre 2006. Société Préhistorique française, Mémoire XLVII de la Société préhistorique française, pp 95-132.

Soriano S (2000) Outillage bifacial et outillage sur éclat au Paléolithique ancien et moyen : coexistence et interaction. Dissertation, Université de Paris X-Nanterre.

Soriano S, Villa P (2017) Early Levallois and the beginning of the Middle Paleolithic in central Italy. PLOS ONE 12 (10): e0186082.

Texier J-P. (Dir.) (2006a) Sédimentogénèse des sites préhistoriques classiques du Périgord. Pôle International de la Préhistoire, Edition numérique.

Texier J-P (2006b) Nouvelle lecture géologique du site paléolithique du Pech-de-l'Azé II (Dordogne, France). Paléo 18: 217-236.

Texier J-P, Bertran P (1993) Nouvelle interprétation paléo-environnementale et chrono-stratigraphique du site de La Micoque (Dordogne). Implications archéologiques. Comptes Rendus de l'Académie des Sciences de Paris 316 II: $1611-1617$.

Thiam D (2018) Approche techno-économique des industries lithiques des grottes de la Terrasse, de Coupe-Gorge, de la Niche, Boule et des Putois, à Montmaurin (Haute-Garonne, France) et potentiel d'application sur quelques sites sénégalais. Dissertation, Université de Perpignan Via-Domitia.

Thiebaut C, Claud E, Mourre V, Chacón Navarro MG, Asselin G, Brenet M, Paravel B (2010) Le recyclage et la réutilisation de nucléus et de bifaces au Paléolithique moyen en Europe occidentale : quelles fonctions et quelles implications culturelles? P@lethnologie Varia.

Tixier J, Turq A (1999) Kombewa et alii. Paléo 11: 135-143.

Torre I de la, Martínez-Moreno J, Mora R (2013) Change and Stasis in the Iberian Middle Paleolithic: Considerations on the Significance of Mousterian Technological Variability. Current Anthropology 54: S320S336.

Tuffreau A, Sommé J (Dir) (1988) Le gisement paléolithique moyen de Biache-Saint-Vaast (Pas-de-Calais), vol. 1 : Stratigraphie, environnement, études archéologiques. Mémoire de la Société Préhistorique française XXI.

Turq A (2000) Le Paléolithique inférieur et moyen entre Lot et Dordogne. Paléo supplément 2, 1.

Turq A (2005) Réflexions méthodologiques sur les études des matières premières lithiques. 1 - Des lithothèques au matériel archéologique. Paléo 17: 111-132.

Turq A, Marcillaud J-G (1976) Les racloirs _a amincissements de type "Kostienki" de la Plane, commune de Mazeyrolles (Dordogne). Bulletin de la Société préhistorique française 73: 75-79.

Turq A, Antignac G, Roussel P (1999) Les silicifications coniaciennes du Sarladais et du Gourdonnais : inventaire et implications archéologiques. Paléo 11: 145-160. 
Turq A, Brenet M, Colonge D, Jarry M, Lelouvier L-A, O'Farell M, Jaubert J (2010) The first human occupations in southwestern France: A revised summary twenty years after the Abbeville/Saint-Riquier colloquium. Quaternary International 223-224: 383-398.

Turq A, Dibble HL, Goldberg P, McPherron SP, Sandgathe D, Jones H, Maddison K, Maureille B, Mentzer S, Rink J, Steenhuyse A (2011) Les fouilles récentes au Pech de l'Azé IV (Dordogne). Gallia Préhistoire 53: 1-58.

Turq A, Faivre J-Ph, Gravina B, Bourguignon L (2017) Building models of Neanderthal territories from raw material transports in the Aquitaine Basin (southwestern France). Quaternary International433(B): 88-101.

Vaquero M, Bargalló A, Chacón Navarro MG, Romagnoli F, Sañudo P (2015) Lithic recycling in a Middle Paleolithic expedient context: evidence from the Abric Romaní (Capellades, Spain). Quaternary International 361: 212-228.

Van Baelen A (2017) The Lower to Middle Palaeolithic Transition in Northwestern Europe. Evidence from Kesselt-Op de Schans. Leuven University Press.

Venditti F, Nunziante-Cesaro S, Parush Y, Gopher A, Barkai R (2019) Recycling for a purpose in the late Lower Paleolithic Levant: Use-wear and residue analyses of small sharp flint items indicate a planned and integrated subsistence behaviour at Qesem Cave (Israël). Journal of Human Evolution 131: 109-128.

Viallet C (2016a) Macrotraces of Middle Pleistocene bifaces from two Mediterranean sites: Structural and Functional analysis. Quaternary International 411 (B): 202-211.

Viallet C (2016b) Potentiel fonctionnel des outils bifaciaux au Pléistocène moyen en contexte méditerranéen. Analyse de la structure et des macro-traces des outils bifaciaux de la Caune de l'Arago, Terra Amata, Orgnac 3 et du Lazaret. Dissertation, Université de Perpignan Via-Domitia.

Villa P (2009) The Lower to Middle Paleolithic Transition (discussion). In: Camps M, Chauhan PR (eds) Sourcebook of Paleolithic Transitions. Methods, Theories and Interpretations. Springer, pp 265-270.

Villaverde V, Eixea A, Joseba RG, Zilhão J (2012) Importancia y valoración de la producción microlevallois en los niveles II y III del Abrigo de La Quebrada (Chelva, Valencia). Zephyrvs 70: 13-32.

Wiśniewski A (2014) The beginnings and diversity of Levallois methods in the early Middle Palaeolithic of Central Europe. Quaternary International 326-327: 364-380.

White M, Ashton N (2003) Lower Palaeolithic core technology and the origins of the Levallois method in NW Europe. Current Anthropology 44: 598-609.

White M, Ashton N, Scott B (2011) The Emergence, Diversity and Significance of Mode 3 (Prepared Core) Technologies. In: Ashton N, Lewis S, Stringer C (eds) The Ancient Human Occupation of Britain, pp 53-66. 


\section{Table legends:}

Table 1: Main characteristics of the sites from this study.

Table 2: Description of raw materials used in the lithic assemblages studied

Table 3: Main categories of lithic pieces in each studied layer. In brackets, counts of tools on flakes (pieces already counted in other flake categories).

Table 4: Type of cores identified per site.

Table 5: Typological counts of flake tools and identified TFU Ts.

\section{Figure legends:}

Figure 1: Main sites between MIS 9 and 6 with a particular focus on Southern France. Stars: studied sites.

Figure 2: Levallois and typo-Levallois technology from Orgnac 3. All flint. A: Levallois recurrent centripetal cores from level 2; B: Levallois flakes from level 2; C: Levallois recurrent centripetal core from level 2; D: Levallois recurrent centripetal core with a last invasive removal from level 2; E: Levallois flake from level 2; F: Typo-Levallois cores (invasive, recurrent) from level 6; G: Mousterian point from level 2.

Figure 3: Levallois technology from south-western France. A: Levallois recurrent bipolar core from level VIIa of Combe-Brune 2; B: Levallois recurrent bipolar core from level L2/3 of La Micoque; C: Levallois recurrent centripetal core with a last invasive removal from level VIIa of Combe Brune 2; D: Levallois flakes (unipolar and bipolar exploitations) from level 7 of Pech-de-l'Azé II, the first is a 'débordant flake'; E: Levallois flake and point from level 2 of Petit-Bost (unipolar and bipolar exploitations); F: Levallois recurrent centripetal core with a flake refitted from level 2 of Petit-Bost (drawing P. Rouzo, INRAP).

Figure 4: Diacritic core sketches. A and C: Levallois cores from level 2 of Orgnac 3; B: Typo-Levallois cores from level 6 of Orgnac 3; D: Levallois core and core-on-flake from level 2 of Petit-Bost; E: Typo-Levallois core and core-on-flake from level L2/3 of La Micoque; F: Levallois recurrent bipolar core from level VIIa of CombeBrune 2.

Figure 5: Cores-on-flakes and microdebitage. A: Recurrent Kombewa cores from level 2 of Petit-Bost; B: Recurrent Kombewa core from level L2/3 of La Micoque; C: Kombewa flakes from level L2/3 of La Micoque; D: Notch-like exploitation from level 2 of Petit-Bost (mixed matrices); E: Lamellar exploitation on the thickness of a broken Levallois core from level 2 of Orgnac 3; E: Dorsal surface exploitation of a flake from level 6 of Orgnac 3; G: Kombewa recurrent cores from level 2 of Orgnac 3; H: Kombewa recurrent core from level VIIa of Combe Brune 2; I: Refitted split flake (both parts retouched after splitting) from level 7 of Pech-de-l'Azé II; J: Discoïd core on flake from level VIIa of Combe Brune 2; K: Kombewa core from level 7 of Pech-de-l'Azé II.

Figure 6: Algorithmic technologies. A: Flake with a cortical back (unipolar exploitation) from level L2/3 of La Micoque; B: SSDA core (two surfaces exploited) from level L2/3 of La Micoque; C: Quina core from level 2 of Petit-Bost (drawing P. Rouzo, INRAP); D: Quina flake from level 2 of Petit-Bost; E: SSDA core from level 2 of Petit-Bost; F: SSDA core from level 6 of Orgnac 3.

Figure 7: Example of tools and TFU analysis. A: Point-like TFU Ts on tools from level 7 of Orgnac 3 (points); B: Linear and denticulate TFU Ts on tools from level 6 of Orgnac 3 (bifacial side scraper and simple denticulate; C: Linear TFU T on tool from level 2 of Orgnac 3 (double side scraper on a Levallois flake); D: Linear TFU Ts on tools from level 7 of Pech de l'Azé II (abrupt side scraper and pedunculate front scraper); Linear and Point-like TFU Ts on tools from level 2 of Petit-Bost (Quina side scraper and convergent side scraper); F: Linear TFU T on a tool from level VIIa of Combe Brune 2 (double side scraper on a large flake). 
Figure 8: Bifaces. A and C: level 6 of Orgnac 3; B: level 2 of Orgnac 3; D, E and F: level 2 of Petit-Bost (E: drawing P. Rouzo, INRAP); G: level 7 of Pech-de-l'Azé II; H and I: level VIIa of Combe-Brune 2 (H: photographs M. Folgado, INRAP).

Figure 9: Trifacial pieces. A: level VIIa of Combe Brune 2; B: level 2 of Petit-Bost (drawing P. Rouzo, INRAP); C: level 6 of Orgnac 3.

Figure 10: Diacritic sketches and TFU Ts of shaped and mixed productions. A: bifacial mixed matrix from level L2/3 of La Micoque; B: bifacial matrix from level 6 of Orgnac 3; C: chopper from level 2 of Orgnac 3; D: chopper from level 7 of Orgnac 3; E: biface on flake from level VIIa of Combe Brune 2; F: triface from level 2 of PetitBost.

Figure 11: Groups identified from the study of unretouched and retouched production on flakes. 